\title{
Hydrogeological characterization and assessment of anthropic impacts in the Lower Piura Sub-basin Aquifer in Peru
}

\author{
Arturo Velasco $^{1}$ - José E. Capilla ${ }^{1}$ \\ Received: 20 September 2018 / Accepted: 7 August 2019/Published online: 29 August 2019 \\ (C) The Author(s) 2019
}

\begin{abstract}
The Lower Piura Sub-basin Aquifer is a vital source of water in the north of Peru. Despite its importance, few local studies describe this formation. Most are limited to reporting hydraulic characteristics and abstraction rates, lacking a broader analysis. This article characterizes the aquifer, presenting the development of a conceptual and mathematical model with sparse data, completed using several assumptions and interpolations. The model will improve understanding of the aquifer system and the impacts of abstraction. The aquifer system includes an unconfined aquifer connected to a confined aquifer through an aquitard. Steady-state and transient-state models from 2004 to 2014 were used. The development and calibration of the model have led to proper identification of hydraulic parameters and boundary conditions, clarifying the dynamics of the system. In the unconfined aquifer, groundwater flows towards the south-west without significant variation in the water table. Conversely, the piezometric surface of the confined aquifer shows a cone of depression with a falling trend of $1.6 \mathrm{~m} /$ year between 2004 and 2014. Outflows include abstractions $\left(48.42 \times 10^{6} \mathrm{~m}^{3} /\right.$ year $)$, gaining surface waters $\left(6.33 \times 10^{6} \mathrm{~m}^{3} /\right.$ year $)$, and sea discharge $\left(18.50 \times 10^{6} \mathrm{~m}^{3} /\right.$ year $)$. Inflows are from irrigation return $\left(34.67 \times 10^{6} \mathrm{~m}^{3} /\right.$ year $)$ and from the Higher Piura Aquifer $\left(27.23 \times 10^{6} \mathrm{~m}^{3} /\right.$ year $)$. The imbalance of $11.24 \times 10^{6} \mathrm{~m}^{3} /$ year is abstracted from aquifer storage leading to hydraulic head drops and flow changes, revealing a clearly unsustainable overexploitation scenario that impacts more intensively the confined aquifer. Model results provide the basis to understand how this is happening and help to suggest strategies to alleviate the current aquifer situation.
\end{abstract}

Keywords Groundwater flow $\cdot$ Numerical modelling $\cdot$ Overexploitation $\cdot$ Coastal aquifers $\cdot$ Peru

\section{Introduction}

Groundwater is a crucial water resource in areas where surface water is scarce or difficult to access. Besides, sustainable development relies not only on the availability of surface water but also on sustainable exploitation of aquifers. The Lower Piura Sub-basin Aquifer located in the north of Peru is an excellent example of a region in which groundwater constitutes a source of water essential for the local economy mainly because of its use in domestic, agricultural, and industrial activities. The presence of groundwater in the Lower Piura Sub-basin was first characterized by Arce (2005) and Bolzicco et al. (2013), who carried out hydrogeological

Arturo Velasco

arveal@ posgrado.upv.es

1 Research Institute of Water and Environmental Engineering, Universitat Politècnica de València, Camino de Vera, $\mathrm{s} / \mathrm{n}$, 46022 Valencia, Spain studies in this area. In this region, there are two main basins, Piura and Chira, which are considered as a unit and are managed following the Plan for the Water Resources Management of the Chira-Piura Basins (ANA 2012b, 2015). Although a considerable quantity of surface water is brought through an interbasin transfer from the Chira Basin to the Piura Basin, a substantial amount of water is still extracted from the aquifer without appropriate management.

The Lower Piura Sub-basin is an agricultural valley located in the lower part of the Piura Basin in the Piura department of Peru. Its arid climate characterizes the area, with average temperatures above $20^{\circ} \mathrm{C}$ and little or no rainfall. However, it is well known that extraordinary precipitation events may occur in the presence of El Niño-Southern Oscillation ENSO (Murphy 1926; Horel and Cornejo-Garrido 1986) with rainfall that surpasses $134 \%$ of the average annual precipitation (Tapley and Waylen 1990). These wet periods alternate with dry periods with a marked influence of the cold current of Humboldt that covers the rest of the year, characterized by strong winds and low temperatures. 
According to Bolzicco et al. (2013), the Lower Piura Subbasin Aquifer lies in the Lower Piura Sub-basin and is made up by Quaternary and Tertiary formations. The Quaternary formations of eolian and fluvial origin make up the upper layer of the aquifer and are characterized by high salt concentrations with conductivities ranging from 1.5 to $8.0 \mathrm{mS} / \mathrm{cm}$. Conversely, the Tertiary formations that make up the underlying confined aquifer have better quality waters with electrical conductivities below $1.5 \mathrm{mS} / \mathrm{cm}$. According to Arce (2005), the Zapallal Tertiary formation is one of the most important geological formations, explored during the 1950s and 1960s for exploitation purposes. The exploration was performed to obtain the water necessary for the recovery of potassium minerals from the brine reservoir south of the Ramón lake. The unconfined aquifer and the confined aquifer are separated by a semipermeable or aquitard layer only a few tens of meters thick (Czech Geological Survey 2010). Due to the good quality of its waters, the confined aquifer is mainly exploited for the urban supply of the main settlements through wells of great depth.

In contrast, the unconfined aquifer is exploited to a lesser extent by shallow open pit wells, and its primary use is for agricultural purposes in rural areas (Bolzicco et al. 2013). Groundwater exploitation records show that both the number of wells and abstraction rates have increased significantly, mainly in the confined aquifer. In 1980, a total of 170 wells pumped $27.01 \times 10^{6} \mathrm{~m}^{3} /$ year, and in 2014 not only the number of wells rose to 398 , but also the abstraction rate doubled to $58.06 \times 10^{6} \mathrm{~m}^{3} /$ year in the whole aquifer system (ONERN 1980; INRENA 2004; ANA 2011, 2012a, 2015). The increase in the number of wells and therefore of the abstractions would not be a problem if this were to occur following adequate planning and management. However, the existing studies are limited to monitoring the quantitative and qualitative status of the aquifer, and there is no understanding of the water flows and balance of the system that allows establishing the basis for sustainable exploitation.

Based on current studies, it is possible to identify the main components of the conceptual model, define the geometry of the system, and estimate hydrodynamic parameters. Thus, the purpose of the research described in this report is to organize and understand the information of previous technical reports, to formulate a conceptual model that explains the current knowledge and observations of the aquifer, and to build a mathematical flow model that allows for verification of the conceptual model and for reproducing the observed behaviour of the aquifer system. Mathematical equations from models describe physical systems, but they are not accurate descriptions of these physical systems or processes. Thus, a mathematical model is a simplified representation of a hydrogeological system that allows predicting, testing, and comparing several scenarios. However, as has been done in this research, the primary use of a mathematical model can be to verify the conceptual model, to identify and calibrate boundary conditions, to understand and interpret the water budget, to estimate the hydrodynamic parameters, and to identify other aspects that require more research (Anderson and Woessner 1992; Bear and Verruijt 1987; Kinzelbach 1986; Freeze and Cherry 1979; Konikow and Bredehoeft 1992). Mathematical models are a powerful research tool in hydrogeology, and their effective use has been demonstrated in this work.

The research described in this report has several objectives that are addressed using the definition and development of a mathematical model. In short, these objectives are: the establishment and validation of a conceptual model, identification of the boundary conditions, water budget identification and understanding, better knowledge of the current aquifer status, and assessment of anthropic impacts. The mathematical model also allows for identifying aquifer system issues that require further research and leads to the establishment of a model able to simulate the system behaviour in different exploitation and climatological scenarios.

To the authors' knowledge, this research provides the first international publication describing and characterizing the Lower Piura Sub-basin aquifer. Therefore, it is useful not only for local authorities and stakeholders but also for the international community since it contributes to improving the knowledge of a coastal aquifer in a world area where, as mentioned by Bocanegra et al. (2009), much more hydrogeological research is needed. Although aquifer overexploitation is not detrimental if it is not permanent, as claimed by Custodio (2002), in this case of study abstractions are permanent and increasing at a constant rate of $0.91 \times 10^{6} \mathrm{~m}^{3} /$ year showing a deficient groundwater management strategy which is leading to groundwater storage depletion, surface-water disconnection, and potential marine intrusion, to mention just the main issues. Despite the uncertainties and lack of information, it can be seen that hydraulic heads are falling at a rate of $1.6 \mathrm{~m} / \mathrm{year}$ in the cone of depression formed around the area of greater exploitation in the confined aquifer. Besides, this aquifer is an excellent example of an overexploitation scenario driven by the increasing demands of high population density in small areas. Thus, the approach and analysis can be used for further research of this groundwater system and as an example to attempt to characterize aquifers in other regions with the same characteristics.

\section{Study area}

The study area is in the department of Piura, approximately $1,027 \mathrm{~km}$ north of the city of Lima, capital of Peru. The analyzed aquifer underlies the Lower Piura Sub-basin, which extends along both banks of the Piura River from the town of Tambogrande to the Pacific Ocean (Fig. 1a). The area belongs to the middle and lower part of the Piura Basin with an area of 


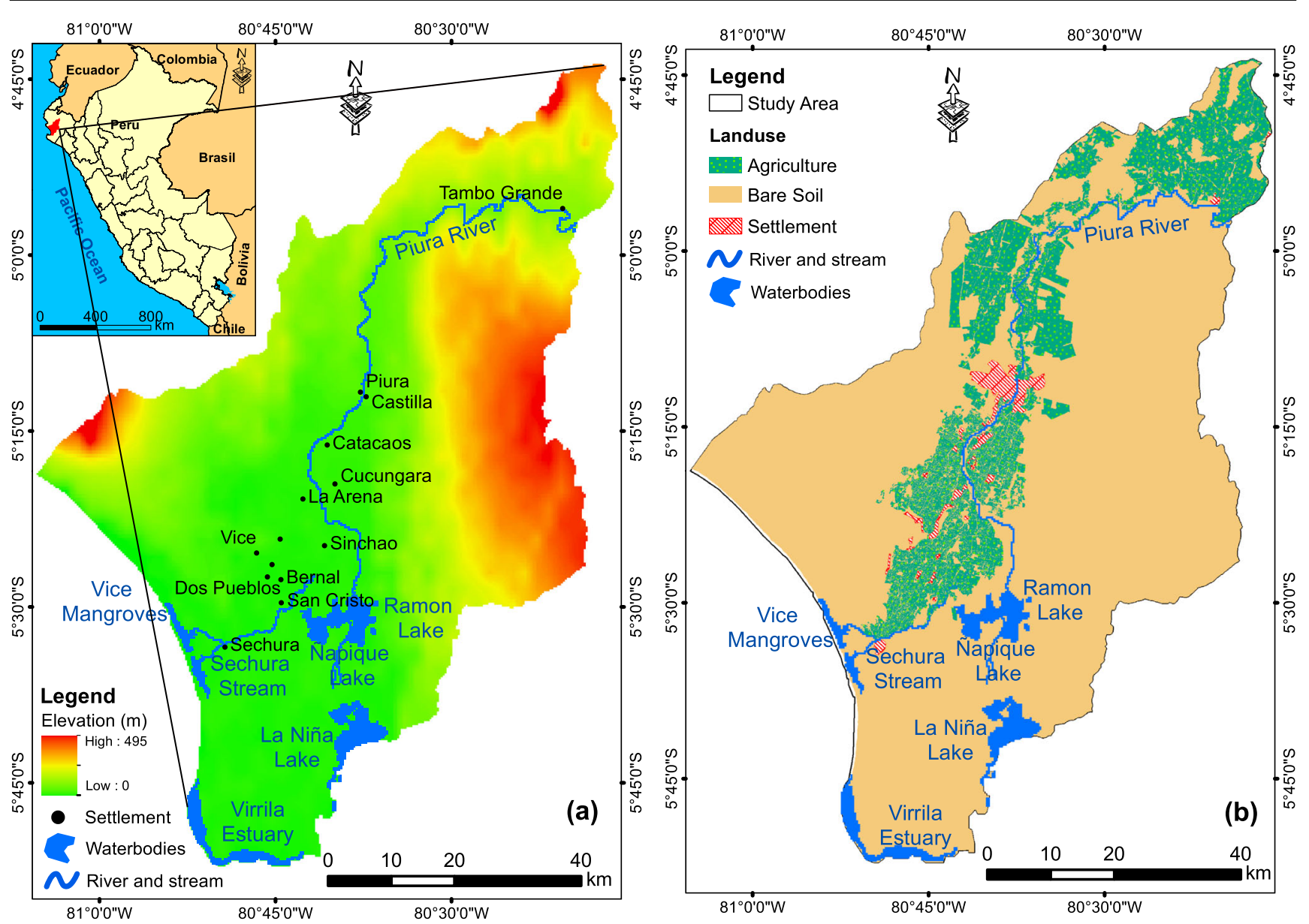

Fig. 1 a Topographic map and $\mathbf{b}$ land use map of the Lower Piura Sub-basin with main water bodies (data from Geoservidor MINAM 2017)

$5,544 \mathrm{~km}^{2}$ characterized by its small water production, moderate slope, and extensive flood plains. The Piura Basin has a total area of $10,872 \mathrm{~km}^{2}$ and its main course, Piura River, has an intermittent hydrological regime (ANA 2012b).

Although a large part of the Lower Piura Sub-basin area is occupied by arid and desert zones (Fig. 1b), the agricultural area under irrigation represents a large area, with rice, lemon, mango and banana being the main crops (ANA 2012a, b, 2015b). However, since the Piura River is an unregulated river with an intermittent regime, there is an interbasin transfer from the Chira Basin located to the north and with a permanent regime. Consequently, the crops' water needs are mostly covered with surface water, with groundwater being used complementarily for agricultural activities.

\section{Climatic conditions and hydrology}

The Lower Piura Sub-basin is characterized by an arid climate with low or no rainfall. According to the meteorological records of the period 1972-2013 from Miraflores Metereological Station, located in the town of Piura, the mean annual precipitation is $77.35 \mathrm{~mm}$, and the mean monthly precipitation ranges between 31 and $52 \mathrm{~mm}$ for summer months (January-April) and between 0.2 and $10 \mathrm{~mm}$ for the rest of the year. However, the presence of ENSO alters these conditions, producing total annual rainfall such as $2,273 \mathrm{~mm}$ in 1983 , and $1,849 \mathrm{~mm}$ in 1998 . These years of extraordinary precipitation generate very high flows in the Piura River, causing extensive flooding of plains and depressions (ClassSalzgitter 2001). Although the influence of this phenomenon in the recharge of the aquifer has not been deeply studied in this area, the Czech Geological Survey (2010) indicated that flood produced by ENSO would not represent a source of recharge for the confined aquifer. This hypothesis may make sense if considering the low permeability of the aquitard and high evaporation rates in this region.

The highest temperatures are observed in the summer, ranging between 24 and $29{ }^{\circ} \mathrm{C}$; in the rest of the year they do not present a significant variation and remain around $20{ }^{\circ} \mathrm{C}$. The average annual relative humidity ranges between 65 and $74 \%$. The region is characterized by high yearly mean evaporation $1,502.50 \mathrm{~mm}$, and mean monthly evaporation ranging between 100 and $154 \mathrm{~mm}$ through the year (data from Proyecto Especial Chira-Piura 2017). 
The main body of surface water in the Lower Piura Sub-basin is the Piura River, which runs through the valley with a southwesterly direction reaching the Ramon and Napique lakes. The mean monthly flows of the Piura River range between 134.61 and $2.05 \mathrm{~m}^{3} / \mathrm{s}$ for summer months and the rest of the year respectively, and there are also records of no-flow during dry years (PNUD 2000, Class-Salzgitter 2001; Galecio 2004). Napique, Ramon and La Niña lakes are of an ephemeral type and dry up due to the high evaporation rates and have a high dependence of flow from the Piura River. In the presence of ENSO, the lakes reach their maximum capacity forming a single body of water with Virrila Estuary, as happened in the years 1983, 1998, 2002 and 2017. In these years, the Piura River reached instantaneous maximum flows higher than $3,000 \mathrm{~m}^{3} / \mathrm{s}$ measured at the Sanchez Cerro Bridge Hydrometric Station in Piura town (ClassSalzgitter 2001; Gore Piura 2017). The Sechura Stream is a seasonal creek currently disconnected from the Piura River, which receives drainage water from the agricultural valley. The Virrila Estuary is a depression that is usually flooded by the sea, but in the presence of extraordinary flows, it connects with La Niña Lake and drains part of the excess flow coming from the Piura River (Czech Geological Survey 2010).

\section{Hydrogeology}

According to the bulletin of the Geological, Mining and Metallurgical Institute of Peru 1994 (INGEMMET 1994), the geomorphology of the Middle and Lower Piura Valley is composed mainly by coastal platform, coastal plain and mountain ranges. The underground geology of the basin is formed by metamorphic rocks, schists, quartzite, phyllite and to a lesser extent paragneiss, orthogneiss, among others. These rocks reach the surface in the Paita massif of Bayóvar, and on the western slopes of the Andean Mountains. Over the underlying geology, the basin is made up by the mantle Chira-Verden (Eocene) that surfaces to the north of Chira; Montera (Miocene), Zapallal (Miocene) covering the Middle and Lower Piura Valley, and Miramar (Miocene) in the Chira and Piura Valley; and the highest mantle Tambogrande (Pliocene) in the San Francisco Sub-basin (Czech Geological Survey 2010). Rock outcrops are extremely scarce due to the full coverage of deposits from the eolian and fluvial origin. The aquifer is near the Sechura Desert plain, which is part of an ancient basin of the Mesozoic, and between the rocky outcrops of the coastal mountain range and the foothills of the western Cordillera of the Andes of north-western Peru (ANA 2015a).

In 1963, using geophysics, Arce (2005) determined that the Quaternary cover of the Lower Piura Sub-basin has a thickness of tens of meters. The Tertiary deposits, where the most important water bodies were found, underlie the Quaternary materials (Bolzicco et al. 2013). However, the geometry and area of them are still not well defined due to the lack of stratigraphic information in the valley.
Bolzicco et al. (2013) estimated that the Tertiary deposits are more than $100 \mathrm{~m}$ deep, with a thickness greater than $100 \mathrm{~m}$ and more than $10,000 \mathrm{~km}^{2}$ in area. This is following geophysical studies carried out by the National Water Authority in 2014 (ANA 2015a) where time-domain electromagnetic and electrical resistivity methods verified the presence and thickness of the confined aquifer. Estimations of the layer thicknesses of the unconfined aquifer, aquitard and confined aquifer are shown in Fig. 2, with their mean thicknesses being 220, 47, and $731 \mathrm{~m}$, respectively. For this study, it has been assumed that horizontally the sub-basin limits the aquifer boundary, and vertically, the aquifer can be represented by three layers, as considered by the Czech Geological Survey (2010). The unconfined aquifer is made up of Quaternary materials, sands with intercalations of gravels and sandstones, with hydraulic conductivity values ranging between 8.64 and $432 \mathrm{~m}$ /day (Czech Geological Survey 2010). The groundwater flows in a southwest direction toward the Pacific Ocean, the water being of poor quality with electrical conductivities between 1.5 and $8.0 \mathrm{mS} / \mathrm{cm}$ (Bolzicco et al. 2013), and mean water table depth of $6.15 \mathrm{~m}$ in the area circumscribed by the pumping wells. The aquitard is a semipermeable formation consisting mainly of clays and sands with a high content of bentonite, having very low hydraulic conductivities ranging between $10^{-2}$ and $10^{-4} \mathrm{~m} /$ day. Coarse-grained sands compose the confined aquifer, and its hydraulic conductivity is estimated between 0.86 and $7.78 \mathrm{~m} /$ day (Czech Geological Survey 2010), with water of better quality with low electrical conductivities of $1.5 \mathrm{mS} / \mathrm{cm}$, according to Bolzicco et al. (2013). In this lower layer, groundwater flows from the Lower Piura Sub-basin boundaries toward its central part due to the cone of depression produced by high pumping abstractions in Piura and Castilla towns. It is very likely that in the absence of abstraction, groundwater has flowed from the confined aquifer to the unconfined one; however, the Czech Geological Survey (2010) pointed out that this might be happening in the opposite way due to the increasing abstraction rates.

The recharge due to rainfall is considered negligible because the Lower Piura Sub-basin is an arid zone with high mean annual evaporation of 1,502.50 mm/year and low mean annual precipitation of $77.35 \mathrm{~mm} /$ year. According to Arce (2005) and Bolzicco et al. (2013), the recharge of the confined aquifer occurs mainly over the middle and upper area of Piura Basin; thus, it is in those areas where the Tertiary formations reach the ground surface. Bolzicco et al. (2013) also mentioned that there is likely a direct recharge from the Piura River to the confined aquifer in the most northern part of the Lower Piura Sub-basin. This assumption is following the conclusions of the Czech Geological Survey (2010) which indicate that a probable recharge of the aquifer would take place in the Piura River between the towns of Tambo Grande and Piura. 

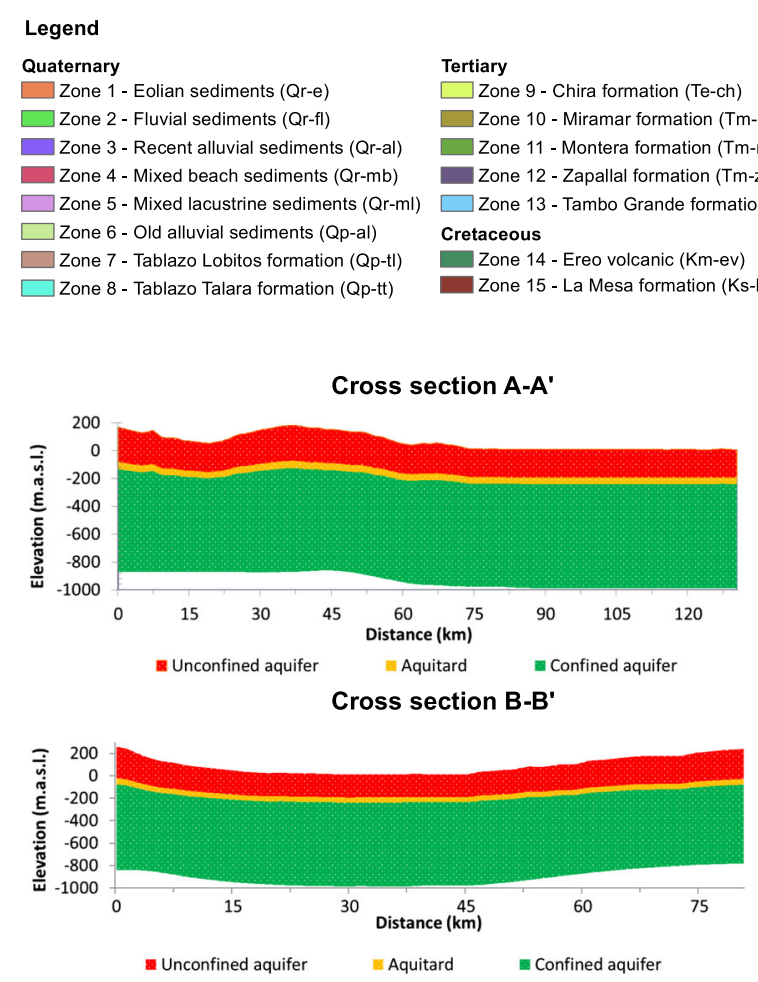
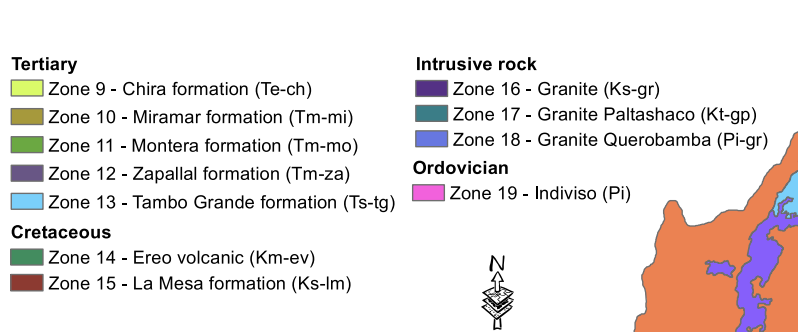
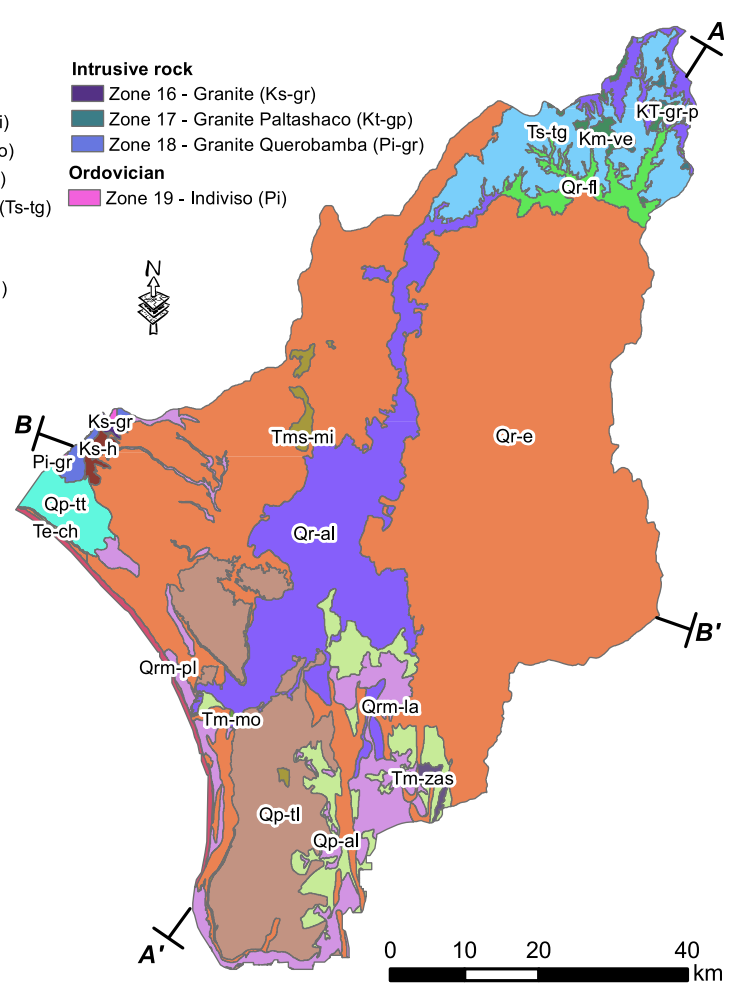

Fig. 2 Geological map of the Lower Piura Sub-basin and hydrogeological zoning for the model (data from GEOCATMIN 2017), Cross sections A-A' and $\mathrm{B}-\mathrm{B}^{\prime}$ show thickness estimations of the unconfined aquifer, aquitard and confined aquifer

Irrigation returns can also represent a substantial part of the recharge in aquifers located in arid areas with intensive agriculture (Molinero et al. 2009), and even more when surface irrigation techniques such as furrow, flood or level basin are used for applying significant water volumes. In the Lower Piura Sub-basin there are four farmers' associationsAssociation of users Chira, Association of users Medio y Bajo Piura, Association of users Sechura, and Association of users San Lorenzo. These farm associations apply a mean annual irrigation rate of $1,406.50 \times 10^{6} \mathrm{~m}^{3} /$ year over a total area of $913.20 \mathrm{~km}^{2}$ of agriculture area (Fig. 1). The gross average yearly irrigation rate is $1,540 \mathrm{~mm} /$ year.

According to data gathered in 2014, the exploitation of the aquifer is mainly for urban use $86.69 \%$, agricultural use $9.25 \%$, and industrial use $4.06 \%$. The highest pumping abstraction rates take place in the confined aquifer due to the good quality of the water, being used to supply drinking water to the population in the main urban settlements. The pumping abstractions of the unconfined aquifer occur to a lower degree with shallow open pit wells and without pumping engines commonly in rural areas for domestic/agricultural activities.

ONERN (1980), INRENA (2004), ANA (2011, 2012a, 2015a) carried out inventories to maintain a record of the number of wells in the area, as well as to estimate the total volume of the abstractions and main hydraulic characteristics of the aquifer. The methodology followed three main steps. The first step was identifying and visiting every well to register the geographic coordinates, while the second was to collect information given by the wells' owners, such as the number of pumping hours, water use, pump characteristics, well dimensions, to mention a few. Finally, for some selected wells, additional information was collected including measured static water levels, $\mathrm{pH}$, electrical conductivity, temperature and total dissolved solids. Usually, these inventories were highly dependent on the willingness of the well's owner to give accurate information about pumping hours and to allow technicians to collect data adequately. Figure $3 \mathrm{~b}$ shows how the number of pumping wells has doubled from 170 to 398 wells between the years 1980 and 2014. The same increasing trend can be seen for pumping abstractions going from $27.01 \times$ $10^{6} \mathrm{~m}^{3} /$ year in 1980 to $58.06 \times 10^{6} \mathrm{~m}^{3} /$ year in 2014 . It is important to note that the inventory carried out in 2011 shows a decrease in pumping abstractions, while the number of wells increases, an inconsistency that could be due to deficiencies in field data collection.

\section{Conceptualization and model set-up}

The Lower Piura Sub-basin Aquifer is mainly made up of the Miramar, Montera and Zapallal Tertiary formations, which are covered by Quaternary sediments of eolian and fluvial origin. The extent of the Tertiary formations and the limits of the confined aquifer are not well defined in the literature. As a result, the perimeter of the Lower Piura Sub-basin with an area of $5,544 \mathrm{~km}^{2}$ has been adopted as the limit of the 

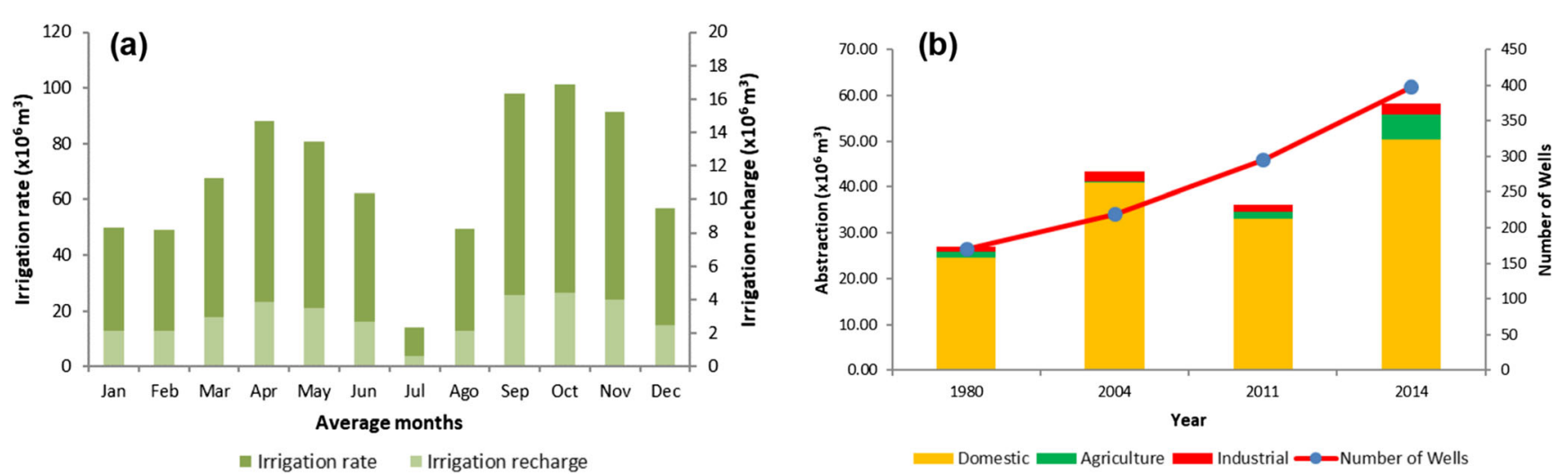

Fig. 3 a Average irrigation rates and estimated effective irrigation recharge, and $\mathbf{b}$ groundwater abstraction and number of wells, within the Lower Piura Sub-basin

hydrogeological model. Further evidence from future field exploration might lead to reconsideration of this assumption. Vertically, the model is divided into three layers, the unconfined aquifer and the lower confined aquifer, connected through an aquitard, which is the semipermeable intermediate layer. Considering the usual range assumed for aquitard hydraulic conductivity $\left(10^{-2}-10^{-4} \mathrm{~m} /\right.$ day $)$, the presence of bentonite, and the uncertainty regarding of its continuity, an estimate of $10^{-2} \mathrm{~m} /$ day is taken for the hydraulic conductivity of this layer. This assumption must be tested in two ways: (1) how it works with the rest of model assumptions during the model calibration, and (2) the following sensitivity analysis once the model is calibrated. The unconfined aquifer is made up of Quaternary formations with higher hydraulic conductivity than the Tertiary formations that make up the lower confined aquifer. The layers of the model were built based on the geophysical surveys carried out by the National Water Authority (2015), and digital elevation models (DEMs) from the Shuttle Radar Topography Mission SRTM with a resolution of 1 arc-second or $30 \mathrm{~m}$ (Rabus et al. 2002).

The numerical model of the Lower Piura Sub-basin Aquifer was built to be run under MODFLOW, the wellknown modelling software of the U.S. Geological Survey (Harbaugh 2005). Thus, a three-dimensional (3D) discretization was designed and managed using the graphical user interface PMWIN Processing MODFLOW software (Simcore Software 2012). The following assumptions and conditions were adopted:

1. Two layers are considered in the discretization. The upper layer corresponds to the unconfined aquifer and the lower one to the confined aquifer; the water storage in the intermediate layer previously mentioned is neglected, and its influence implicitly accounted for by the vertical hydraulic conductivity. For this regionalscale flow model, the inclusion of an additional layer to represent the aquitard would increase the running times without any benefit. It is a guiding principle for this type of model to represent aquitards with a lower vertical hydraulic conductivity that simulates the effect of the low values of hydraulic conductivity of the aquitard materials.

2. The area of the two layers of the model is inscribed in a rectangle of $91,500 \mathrm{~m} \times 126,000 \mathrm{~m}$, regularly discretized in 305 columns and 420 rows respectively, with a grid cell size of $300 \times 300 \mathrm{~m}$. The geographical orientation of the grid is from the north to the south, as can be seen in Fig. 5. The dimensionality, the size and the discretization are chosen to reproduce the conceptual model appropriately and to allow a reasonable calibration for this scale model with a higher density of water abstraction wells in the central area.

3. The active area of the model - active grid blocks of the discretization - has been organized into 19 zones classified according to the mapped geology in Fig. 2, where the values of horizontal hydraulic conductivity, specific storage, specific yield and effective porosity are assigned individually. The initial and calibrated values for each homogeneous zone can be seen in Table 1 .

4. Because the hydraulic conductivity of wide areas is close to the order of magnitude of $1 \mathrm{~m} /$ day, an anisotropy factor of 100 is taken to reproduce the estimated conductivity of $10^{-2} \mathrm{~m} /$ day for the aquitard layer. Thus, the vertical hydraulic conductivity will represent the effect of the low conductivity of the aquitard in the connection between the two layers. This vertical anisotropy factor is assumed homogeneous for the whole aquifer and implies that the vertical hydraulic conductivity is one-hundredth of the corresponding horizontal value in every gridlock.

5. The modelling period available for the model calibration is 10 years and 1 month - from October 2004 to October 2014 - and it is divided into monthly periods that correspond to 121 stress periods as defined in MODFLOW.

6. The estimated initial hydraulic head, when solving the steady-state flow scenario described below, corresponds 
Table 1 Initial and calibrated hydraulic parameters of the groundwater model

\begin{tabular}{|c|c|c|c|c|c|c|c|c|c|c|}
\hline \multirow[t]{3}{*}{ Zone } & \multicolumn{4}{|c|}{ Initial hydraulic parameters } & \multicolumn{6}{|c|}{ Calibrated hydraulic parameters } \\
\hline & \multirow[b]{2}{*}{$K$ (m/day) } & \multirow[b]{2}{*}{$S_{\mathrm{s}}\left(\mathrm{m}^{-1}\right)$} & \multirow[b]{2}{*}{$S_{\mathrm{y}}$} & \multirow[b]{2}{*}{$n_{\mathrm{e}}$} & \multicolumn{2}{|c|}{ Unconfined aquifer } & \multicolumn{4}{|c|}{ Confined aquifer } \\
\hline & & & & & $K$ (m/day) & $S_{\mathrm{y}}$ & $n_{\mathrm{e}}$ & $K$ (m/day) & $S_{\mathrm{s}}\left(\mathrm{m}^{-1}\right)$ & $n_{\mathrm{e}}$ \\
\hline 1 & 1.00 & $1.0 \times 10^{-4}$ & 0.32 & 0.32 & 4.42 & 0.19 & 0.19 & 0.19 & $1.4 \times 10^{-4}$ & 0.19 \\
\hline 2 & 0.10 & $1.0 \times 10^{-4}$ & 0.15 & 0.15 & 3.97 & 0.09 & 0.09 & 0.49 & $5.0 \times 10^{-3}$ & 0.09 \\
\hline 3 & 0.14 & $1.0 \times 10^{-4}$ & 0.15 & 0.15 & 3.61 & 0.09 & 0.09 & 0.27 & $1.8 \times 10^{-3}$ & 0.09 \\
\hline 4 & 1.00 & $1.0 \times 10^{-4}$ & 0.30 & 0.30 & 4.53 & 0.15 & 0.15 & 0.10 & $1.2 \times 10^{-3}$ & 0.15 \\
\hline 5 & 1.00 & $1.0 \times 10^{-4}$ & 0.25 & 0.25 & 3.03 & 0.15 & 0.15 & 0.20 & $7.0 \times 10^{-3}$ & 0.15 \\
\hline 6 & 0.10 & $1.0 \times 10^{-4}$ & 0.15 & 0.15 & 3.75 & 0.09 & 0.09 & 0.75 & $1.4 \times 10^{-3}$ & 0.09 \\
\hline 7 & 5.00 & $1.0 \times 10^{-4}$ & 0.32 & 0.32 & 4.53 & 0.19 & 0.19 & 0.44 & $1.1 \times 10^{-3}$ & 0.19 \\
\hline 8 & 2.00 & $1.0 \times 10^{-4}$ & 0.33 & 0.33 & 4.53 & 0.20 & 0.20 & 1.80 & $2.3 \times 10^{-3}$ & 0.20 \\
\hline 9 & 1.39 & $5.0 \times 10^{-5}$ & 0.21 & 0.21 & 0.15 & 0.13 & 0.13 & 0.50 & $2.1 \times 10^{-3}$ & 0.13 \\
\hline 10 & 1.00 & $5.0 \times 10^{-5}$ & 0.21 & 0.21 & 2.11 & 0.13 & 0.13 & 0.16 & $1.0 \times 10^{-3}$ & 0.13 \\
\hline 11 & 1.00 & $5.0 \times 10^{-5}$ & 0.22 & 0.22 & 0.10 & 0.13 & 0.13 & 0.50 & $2.0 \times 10^{-3}$ & 0.13 \\
\hline 12 & 1.00 & $5.0 \times 10^{-5}$ & 0.14 & 0.14 & 0.39 & 0.08 & 0.08 & 0.82 & $1.5 \times 10^{-3}$ & 0.08 \\
\hline 13 & 1.00 & $5.0 \times 10^{-5}$ & 0.32 & 0.32 & 1.00 & 0.19 & 0.19 & 0.74 & $3.0 \times 10^{-3}$ & 0.19 \\
\hline 14 & 0.03 & $5.0 \times 10^{-5}$ & 0.26 & 0.26 & 0.03 & 0.16 & 0.16 & 0.03 & $2.0 \times 10^{-3}$ & 0.16 \\
\hline 15 & 0.10 & $5.0 \times 10^{-5}$ & 0.21 & 0.21 & 0.08 & 0.13 & 0.13 & 0.38 & $1.0 \times 10^{-3}$ & 0.13 \\
\hline 16 & 0.03 & $5.0 \times 10^{-5}$ & 0.26 & 0.26 & 0.01 & 0.16 & 0.16 & 0.03 & $9.0 \times 10^{-3}$ & 0.16 \\
\hline 17 & 0.03 & $5.0 \times 10^{-5}$ & 0.26 & 0.26 & 0.01 & 0.16 & 0.16 & 0.03 & $4.0 \times 10^{-5}$ & 0.16 \\
\hline 18 & 0.03 & $5.0 \times 10^{-5}$ & 0.26 & 0.26 & 0.01 & 0.16 & 0.16 & 0.03 & $6.0 \times 10^{-3}$ & 0.16 \\
\hline 19 & 0.03 & $5.0 \times 10^{-5}$ & 0.26 & 0.26 & 0.02 & 0.16 & 0.16 & 0.03 & $8.0 \times 10^{-3}$ & 0.16 \\
\hline
\end{tabular}

to hydraulic heads of October 2004 (Fig. 4). Data from observation wells were used to build the initial hydraulic head surface for the specific month, by using the Kriging method with a spherical semivariogram model, a maximum distance of 10,626 $\mathrm{m}$ and a maximum number of points equal to 5 . These are reasonable parameters for the interpolation of heads, in the absence of structural analysis and trends.

7. The initial piezometric-head field when solving transient simulations corresponds to the hydraulic-head field obtained from the steady-state model. It is good practice to avoid spurious results at early times in the transient model run using initial conditions obtained from a previous run like a calibrated steady-state run.

8. The main recharging inflow of the system is the recharge from irrigation returns which amounts to $56.26 \times$ $10^{6} \mathrm{~m}^{3} /$ year or $61.60 \mathrm{~mm} /$ year. Other fundamental inflow takes place through the boundary with the Higher Piura Aquifer.

9. The exploitation of the aquifer for the simulation period considered is poorly characterized. It was estimated as $43.27 \times 10^{6} \mathrm{~m}^{3} /$ year in 2004 , and $58.06 \times 10^{6} \mathrm{~m}^{3} /$ year in 2014. The exploitation between years 2004 and 2014 was estimated by interpolation.
10. The hydraulic connection of the groundwater body with the river and other surface water bodies was modelled using the River Package of MODFLOW. The average surface water level was estimated from previous studies such as Class-Salzgitter (2001), Galecio (2004) and the Czech Geological Survey (2010). According to these reports, Piura River has a mean width ranging between 100 and $150 \mathrm{~m}$ with an average width/depth ratio equal to 20 , and average water depth ranging from 0.5 to $1.0 \mathrm{~m}$.

11. The discharge to the sea is modelled representing the sea boundary as a constant head boundary. Considering the report of Schuckmann et al. (2016), a sea level of $0.8 \mathrm{~m}$ above sea level (asl) is assumed.

12. The boundary with the Higher Piura Aquifer is modelled with a general head boundary (GHB) condition. ANA 2015a estimated that the lateral flow transferences from the Higher Piura Aquifer to the northeast of the Lower Piura Sub-basin Aquifer do not exceed $41.53 \times 10^{6} \mathrm{~m}^{3} /$ year.

13. The hydrogeological formation perimeter, except for the sea boundary and the connection with the Higher Piura Aquifer, is considered as an impervious or no-flow boundary. Based on previous 


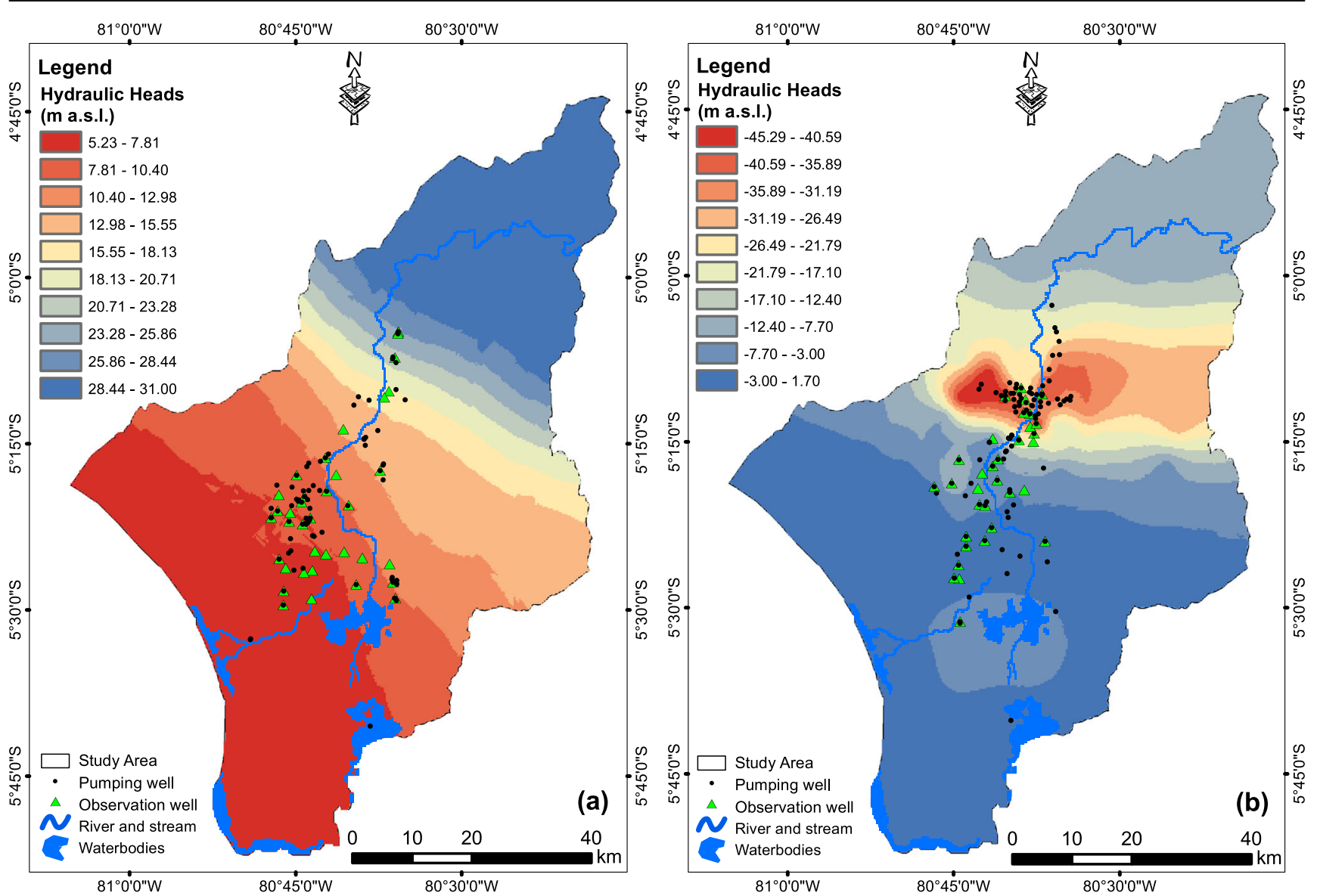

Fig. 4 Observed hydraulic heads for October 2004 and spatial distribution of pumping and observation wells in the a unconfined aquifer and $\mathbf{b}$ confined aquifer

studies and considerations of the Czech Geological Survey (2010), this outer limit is estimated, assuming that the groundwater divide is close to the drainage divide. Although it seems quite a sound hypothesis, future field exploration might change this assumption.

\section{Hydraulic parameters}

The initial hydrodynamic parameters of the model were established within the ranges of values indicated in the National Water Authority study by ANA (2015a), and the Czech Geological Survey (2010) study. The estimated values given in these studies together with estimations based on analogue hydrogeological formations, served to estimate the initial parameters of the model such as hydraulic conductivity $K$, specific storage $S_{\mathrm{s}}$, specific yield $\mathrm{S}_{\mathrm{y}}$, and effective porosity $n_{\mathrm{e}}$, given in Table 1.

\section{Boundary conditions}

The groundwater in this aquifer would flow under natural conditions towards the Pacific Ocean boundary, where a constant hydraulic head of $0.8 \mathrm{~m}$ asl is set (Schuckmann et al. 2016). Thus, discharge to the sea is modelled with a constant head boundary condition, which is a reasonable simplification given the regional scale of the models and being unnecessary to model seawater intrusion. Along the northeast limit, a GHB condition has been established in order to model the recharge coming from the Higher Piura Aquifer. This is a type of boundary condition, known as Cauchy condition, where an external head and a hydraulic conductance or resistance are specified to represent the effects of connection between the two groundwater bodies, and these parameters are estimated by trial and error considering that the water transfer cannot exceed previous estimations of $41.53 \times 10^{6} \mathrm{~m}^{3} /$ year by ANA (2009a) and ANA (2015a). The flows between the aquifer and the water bodies were modelled using the MODFLOW River Package. This package models the water transfer as a Cauchy condition requiring external heads and hydraulic conductance values that were estimated based on the local topography, river 
geometry and estimations of water levels from previous studies such as Class-Salzgitter (2001), Galecio (2004) and Czech Geological Survey (2010). Finally, the remaining perimeter of the model, given by the eastern and western boundaries of the model, see Fig. 5, are assumed as no-flow limits.

\section{Recharge and abstractions}

The main inflows to the Lower Piura Sub-basin Aquifer come from the irrigation returns and lateral recharge from the adjacent Higher Piura Aquifer. The aquifer is also recharged from some Piura River reaches, and by infiltration from the lakes. Recharge from precipitation has been considered negligible. The mean annual recharge from irrigation returns has been estimated as $10 \%$ of the losses of water applications in crops (SEA 2012) considering an irrigation efficiency of 60\% in this region (ANA 2012b). As a result, a mean annual effective recharge of $56.26 \times 10^{6} \mathrm{~m}^{3} /$ year is obtained, which is distributed over the $913.20 \mathrm{~km}^{2}$ of agricultural area (Fig. 1b), which represents an effective recharge of $61.60 \mathrm{~mm} /$ year. This value was used in the first approximations of the steady-state model for October 2004. For the transient state model, the seasonal variation of irrigation was incorporated, obtained from ANA (2009b, 2015b), considering the timing and phenology of the agricultural campaign (see Fig. 3a). The lateral recharge coming from the Higher Piura Aquifer was estimated in the study carried out by the National Water Authority ANA (2015a) where a water balance of the entire Piura Basin was made estimating a lateral recharge of $41.53 \times 10^{6} \mathrm{~m}^{3} /$ year toward the Lower Piura Sub-basin Aquifer.

On the other hand, the pumping abstractions in 2004 were $43.27 \times 10^{6} \mathrm{~m}^{3} /$ year, and it is estimated that $1.67 \times 10^{6} \mathrm{~m}^{3} /$ year were abstracted from the unconfined aquifer, and $41.60 \times 10^{6} \mathrm{~m}^{3} /$ year from the confined aquifer. In 2014 the abstractions amounted to $58.06 \times 10^{6} \mathrm{~m}^{3} /$ year, estimating that $3.36 \times 10^{6} \mathrm{~m}^{3} /$ year were abstracted from the unconfined aquifer and $54.7 \times 10^{6} \mathrm{~m}^{3} /$ year from the confined aquifer. The estimations of the pumping rates, for both the unconfined and confined aquifer, were obtained based on the characteristics of the pumping wells, such as electrical conductivity, well depth, type of well (open pit well or drilled well), and spatial correspondence with adjacent hydraulic heads observed. Shallow open pit wells with electrical conductivity higher than $2.0 \mathrm{mS} / \mathrm{cm}$, and low depth were considered as belonging to the unconfined aquifer. Conversely, drilled wells with low electrical conductivity and high depth were considered as belonging
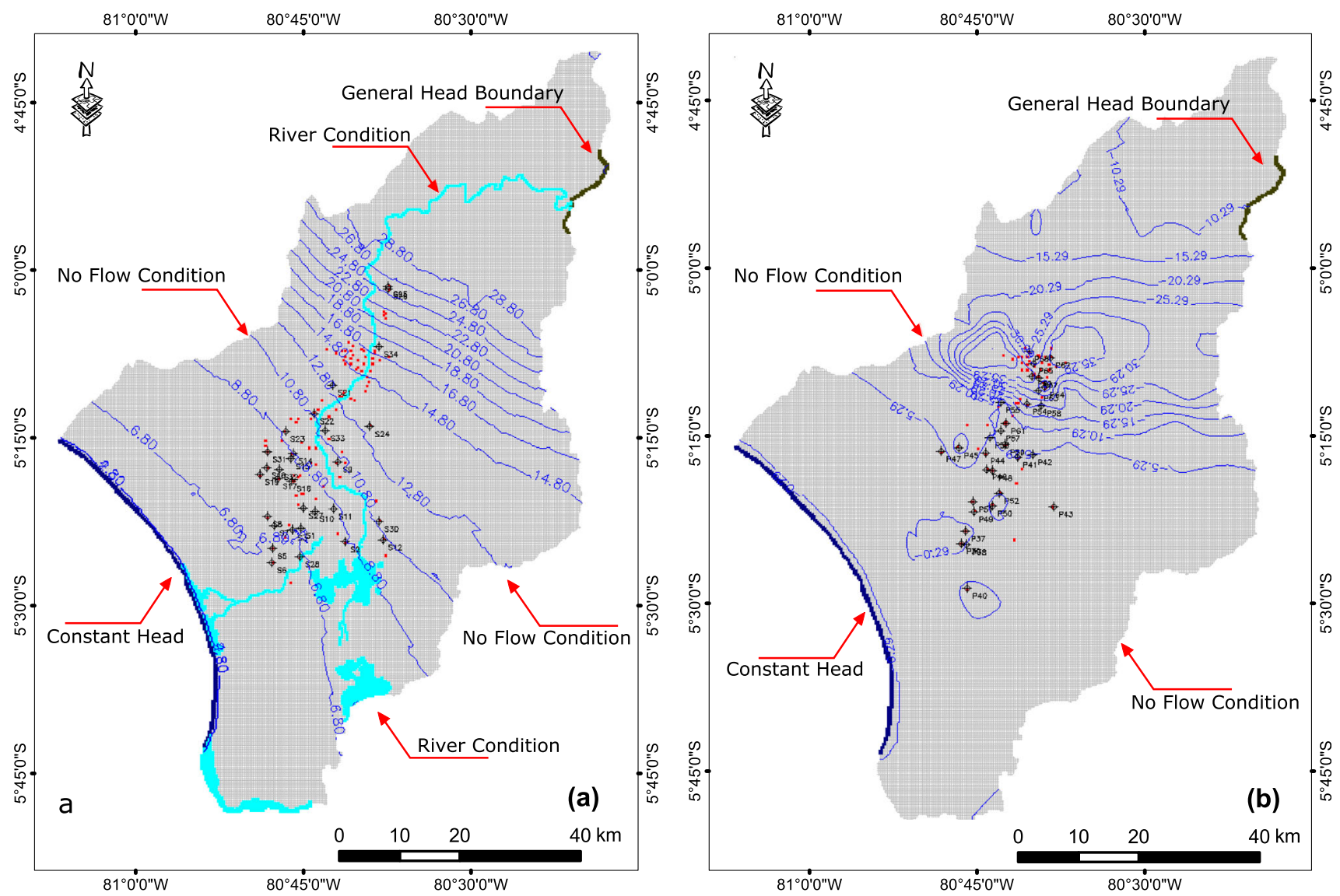

Fig. 5 Discretization and boundary conditions of the a unconfined aquifer and $\mathbf{b}$ confined aquifer. Hydraulic heads correspond to observations of October 2004, black and red dots represent observation and pumping wells respectively 
to the confined aquifer. Once this classification was done, it was verified that there is a correspondence of the adjacent hydraulic heads between wells belonging to each layer.

\section{Model calibration}

The calibration process is generally understood as the process that seeks to identify the model parameters, often including the boundary conditions and other external stresses, to minimize the differences between the observed hydraulic heads and those resulting from the model. It is common to carry out a trial-and-error approach that can yield reasonably accurate results when the knowledge of the aquifer description and parameters is limited. Automatic calibration algorithms and, in general, inverse modelling methodologies are always an applicable tool and can also be combined with initial trialand-error adjustments. Moreover, stochastic inverse modelling approaches should be considered as the most accurate tool to obtain results where the uncertainty of parameters is accounted for, requiring knowledge of the aquifer and parameters with some characterization of their uncertainty. However, the current knowledge of the Lower Piura Sub-basin Aquifer calls for a trialand-error approach together with the application of automatic algorithms to improved results. The application of more complex methodologies to characterize the uncertainty of the calibration results is unfeasible with the currently available data.

The objective of the calibration procedure has been to reproduce the observed hydraulic heads of 60 pumping wells between 2004 and 2014, monitored by the National Water Authority ANA (2015a). In order to do that, the wells belonging to the unconfined and confined aquifer were identified, obtaining 36 wells representative of the unconfined aquifer and 33 representatives of the confined aquifer. The criterion used to classify them was the same used for the classification of the pumping wells since most of them serve as observation and pumping wells at the same time.

The first calibration carried out was for steady-state flow conditions. Following a universal guiding principle in groundwater flow modelling, the first step was to calibrate a steady-state model before dealing with the transient-state calibration. The possibility of calibrating the model under natural pre-exploitation conditions was considered unfeasible due to the lack of historical data and low representativeness that effective parameters obtained for that regime would have for the current state of the aquifer. As described in previous sections, based on referred studies, the aquifer presents significant changes in flow regime, flow directions and in piezometric heads, mainly in the confined layer. This situation calls for a steady-state calibration that can yield parameters and initial heads closer to the general situation in which the transient model is going to be calibrated. In this steady-state calibration, both recharge due to irrigation returns, and hydraulic conductivity values were addressed. The calibration of hydraulic conductivity was conducted using the PEST automatic calibration model (Doherty 2016), while the conventional trial-anderror methodology was used to calibrate recharge and conductance for the Piura River, lakes, and the GHB condition imposed for the connection to the Higher Piura Aquifer. The hydraulic conductivity $(K)$ values obtained for the unconfined aquifer were between 0.01 and $4.53 \mathrm{~m} / \mathrm{day}$, and for the confined aquifer between 0.03 and $1.80 \mathrm{~m} /$ day, as shown in Table 1 . The calibrated value for irrigation returns recharge was $144,696 \mathrm{~m}^{3} /$ day $(0.1584 \mathrm{~mm} /$ day $)$, slightly lower than the value established in the conceptual model, while the calibrated hydraulic conductance for water bodies and the GHB condition in the northeast limit were $300 \mathrm{~m}^{2} /$ day and $1,684.8 \mathrm{~m}^{2} /$ day, respectively. The efficiency of the calibration of the steady-state model is presented graphically and numerically in Fig. 6a, where observed hydraulic heads are compared with calculated heads. A graph showing the frequency distribution of the errors is also presented. The results obtained are quite good, considering the regional scale of the model and, for both the unconfined aquifer and the confined aquifer, most of the observations and calculated values are aligned in a 1:1 ratio. The greatest discrepancies are observed in the confined aquifer, due to greater uncertainty in this lower formation. Despite that, the frequency distribution graph of errors shows a reasonable adjustment of the model to reproduce the observed values (Moriasi et al. 2007). The higher proportion of the errors is distributed around 0 , between $+2 \mathrm{~m}$ and $-2 \mathrm{~m}$, with an equal standard deviation $2.54 \mathrm{~m}$, mean square error (MSE) $6.37 \mathrm{~m}$, correlation coefficient 0.99 , Nash-Shuttle efficiency (NSE) 0.97 , and model balance error equal to $0.00 \%$.

The previously calibrated steady-state model was used as a starting point for calibration of the transient state model. The trial-and-error approach was used to calibrate the specific storage, specific yield and drainage porosity. Some attempts were made to recalibrate horizontal hydraulic conductivities previously obtained with the steady-state model, but the improvements in the reproduction of observed hydraulic heads were not significant; thus, the values calibrated for steady-state were retained. The calibrated values of the specific storage are between $4 \times 10^{-5}$ and $1 \times 10^{-3} \mathrm{~m}^{-1}$, and specific yield and drainage porosity between 0.09 and 0.20 , as can be seen in Table 1. The fact that it is a transient model where there are more data to honour- 528 hydraulic head measurements against 60 measurements in 

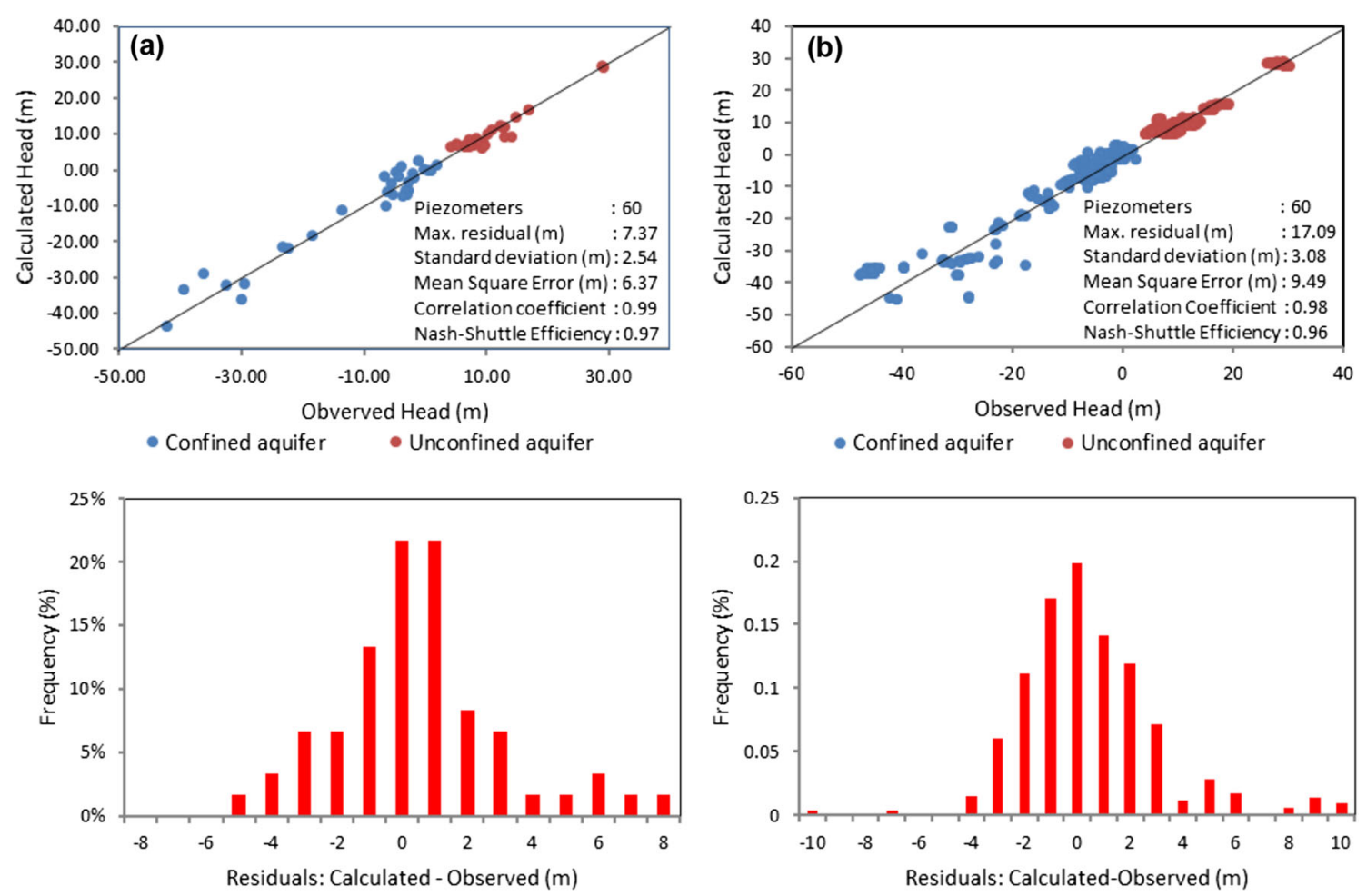

Fig. 6 Model calibration results: observed versus simulated hydraulic heads, and frequency distribution of hydraulic head residuals for the a steady-state condition and $\mathbf{b}$ transient condition

the steady-state case - increases the difficulty of the calibration significantly. Besides, the impact on the results of the aquifer characterization and external-stress uncertainties grows significantly. As indicated before, even pumping abstractions have been interpolated, and the location of some wells in the upper or lower aquifer layer might be reconsidered if more information were available. Regardless, it can be observed that there is no identifiable pattern of underestimation or overestimation of the hydraulic heads in the confined aquifer, indicating that these errors are not only produced by the uncertainties of the conceptual model, but also they can be a result of systematic errors in the reading of some hydraulic head levels, especially considering that the piezometric network is monitoring active pumping wells and not static piezometers. Despite these discrepancies, the statistics show that there is a good fit of the model to reproduce the observed hydraulic heads (Moriasi et al. 2007), with a standard deviation of $3.08 \mathrm{~m}$, MSE $9.49 \mathrm{~m}$, correlation coefficient 0.98, NSE 0.96, and model balance error of $-0.14 \%$. Although the maximum residual equals $17.09 \mathrm{~m}$, this extreme value does not represent the overall efficiency of the model since the frequency distribution graph shows a normal distribution of errors around $0 \mathrm{~m}$.

As a general conclusion, the graphical and statistical evaluation of the calibration results, both for the steady and transient state models, show a reasonably good fit demonstrating its ability to reproduce the general behaviour of the aquifer system adequately. However, among the different uncertainties of the model, there is the fact that piezometric head measurement locations are concentrated in the central area of the model, so there is no information to validate the model behaviour in outer regions.

\section{Sensitivity analysis}

A sensitivity analysis to variations of some important parameters of the model was performed in the steadystate model. This helped to assess the robustness of the mathematical model and did not provide reasons that would recommend the recalibration or reformulation of the conceptual model. However, its conclusions can also help to design future field surveys of the aquifer by addressing some parameters that have a stronger influence in model results. Among these conclusions, the following are highlighted (Table 2).

- The reproduction of observed hydraulic heads is much more sensitive to the variations of hydraulic conductivity of the confined aquifer than to variations in the unconfined aquifer. 
Table 2 Sensitivity analysis for the steady-state groundwater model

\begin{tabular}{lccccccc}
\hline Parameter & Layer & Change $(\%)$ & NSE & $\begin{array}{l}\text { Lateral inflow } \\
\left(\mathrm{m}^{3} / \text { day }\right)\end{array}$ & $\begin{array}{l}\text { Water bodies } \\
\left(\mathrm{m}^{3} / \text { day }\right)\end{array}$ & $\begin{array}{l}\text { Layer exchange } \\
\left(\mathrm{m}^{3} / \text { day }\right)\end{array}$ & $\begin{array}{l}\text { Sea outflow } \\
\left(\mathrm{m}^{3} / \text { day }\right)\end{array}$ \\
\hline Hydraulic conductivity & 1 & +25 & 0.9708 & $86,875.06$ & $52,632.47$ & $84,621.72$ & $61,031.12$ \\
& & -25 & 0.9720 & $66,165.09$ & $44,035.59$ & $85,965.31$ & $48,918.29$ \\
Hydraulic conductivity & 2 & +25 & 0.9055 & $78,451.86$ & $48,462.50$ & $85,389.09$ & $56,778.13$ \\
& & -25 & 0.8165 & $75,412.98$ & $48,476.44$ & $84,967.45$ & $53,725.13$ \\
Vertical Anisotropy & 1 and 2 & +25 & 0.9509 & $76,649.49$ & $48,903.39$ & $85,073.70$ & $54,534.61$ \\
& & -25 & 0.9265 & $77,355.11$ & $48,079.59$ & $85,222.87$ & $56,063.84$ \\
Hydraulic conductance River and lakes & 1 & +50 & 0.9716 & $89,618.96$ & $49,411.42$ & $85,518.48$ & $66,996.12$ \\
& & -50 & 0.9719 & $59,394.14$ & $44,735.75$ & $85,015.17$ & $41,447.02$ \\
GHB conductance Lateral recharge & 1 and 2 & +50 & 0.9722 & $79,514.64$ & $51,041.73$ & $85,221.88$ & $55,261.88$ \\
& & -50 & 0.9722 & $70,972.58$ & $42,501.72$ & $85,143.31$ & $55,259.67$ \\
Irrigation recharge & 1 & +50 & 0.9562 & $73,423.04$ & $113,597.55$ & $87,982.88$ \\
& & -50 & 0.9522 & $80,598.21$ & $-16,080.83$ & $82,221.66$ \\
Steady-state calibrated model & - & - & 0.9722 & $76,937.64$ & $48,465.03$ & $85,199.15$ \\
\hline
\end{tabular}

- Lower vertical anisotropy deteriorates the effectiveness of the model calibration, but it does not show important variations in the model fluxes.

- The values adopted for conductance in rivers and lakes are quite well adjusted; the sensitivity of these conductances causes a poorer reproduction of observed heads and has a meagre impact on water flows between the aquifer and surface water bodies.

- The conductance adopted to model the lateral recharge coming from the Higher Piura Aquifer does not affect the calibration of the model. However, the locations of the available piezometric measurements are far from this aquifer boundary; thus, further research in other areas of the aquifer might lead to different conclusions.

- The variation of irrigation recharge has a significant impact on the exchange of flows between the aquifer and surface-water bodies, affecting the reproduction of observed heads mainly in the unconfined aquifer. This result calls for further research on the water budgets and dynamics of surface-water bodies connected to the groundwater body.

\section{Results and discussion}

The rates of groundwater extraction from the aquifer have followed a growing trend during the last decades, as described in the inventories carried out by the National Water Authority ANA (2011, 2012a, 2015a), and predecessor institutions ONERN (1980) and INRENA (2004). However, the research presented in this report constitutes the first attempt to analyze how this extraction trend affects hydraulic heads, underground flows and hydraulic connections between surface water and groundwater.

In Fig. 7, the evolution of the hydraulic head in selected piezometers located in the unconfined aquifer and the underlying confined aquifer are represented. The calibrated model captures reasonably well the observed trends of hydraulic heads. In the unconfined aquifer, the water table decreases very slightly during the analyzed period-this upper water body is less exploited due to its higher concentrations of salt. The minimum, maximum and mean hydraulic head in the unconfined aquifer are $0.8,70.51$, and 18.82 masl for 2004, whereas for 2014 they are $-0.58,70.31$, and 18.72 masl, respectively. On the other hand, the piezometric surface in the confined aquifer tends to decrease during the simulation period, as shown by the observed data, due to the constant and growing extraction, mainly for urban supply. The minimum, maximum and mean hydraulic heads in the confined aquifer are -56.24 , 69.00, and 15.99 m.asl for 2004, whereas for 2014 they are $-72.33,69.00$, and 15.79 masl, respectively.

The model calibration has been done using a hydrological regime representative of average years; therefore, it is not possible to reproduce variations of hydraulic heads due to specific temporal hydrological phenomena. Despite this, the model approximately represents the anthropic influence in the long term and reproduces the observed behaviour of both the unconfined and confined aquifers. As can be seen in Fig. 8, water in the unconfined aquifer flows following a southwest direction towards the Pacific Ocean, and there are no important changes of hydraulic head in the simulated period. However, the situation is different in the confined aquifer 
Fig. 7 Hydraulic heads at some selected control points for the a unconfined aquifer and $\mathbf{b}$ confined aquifer
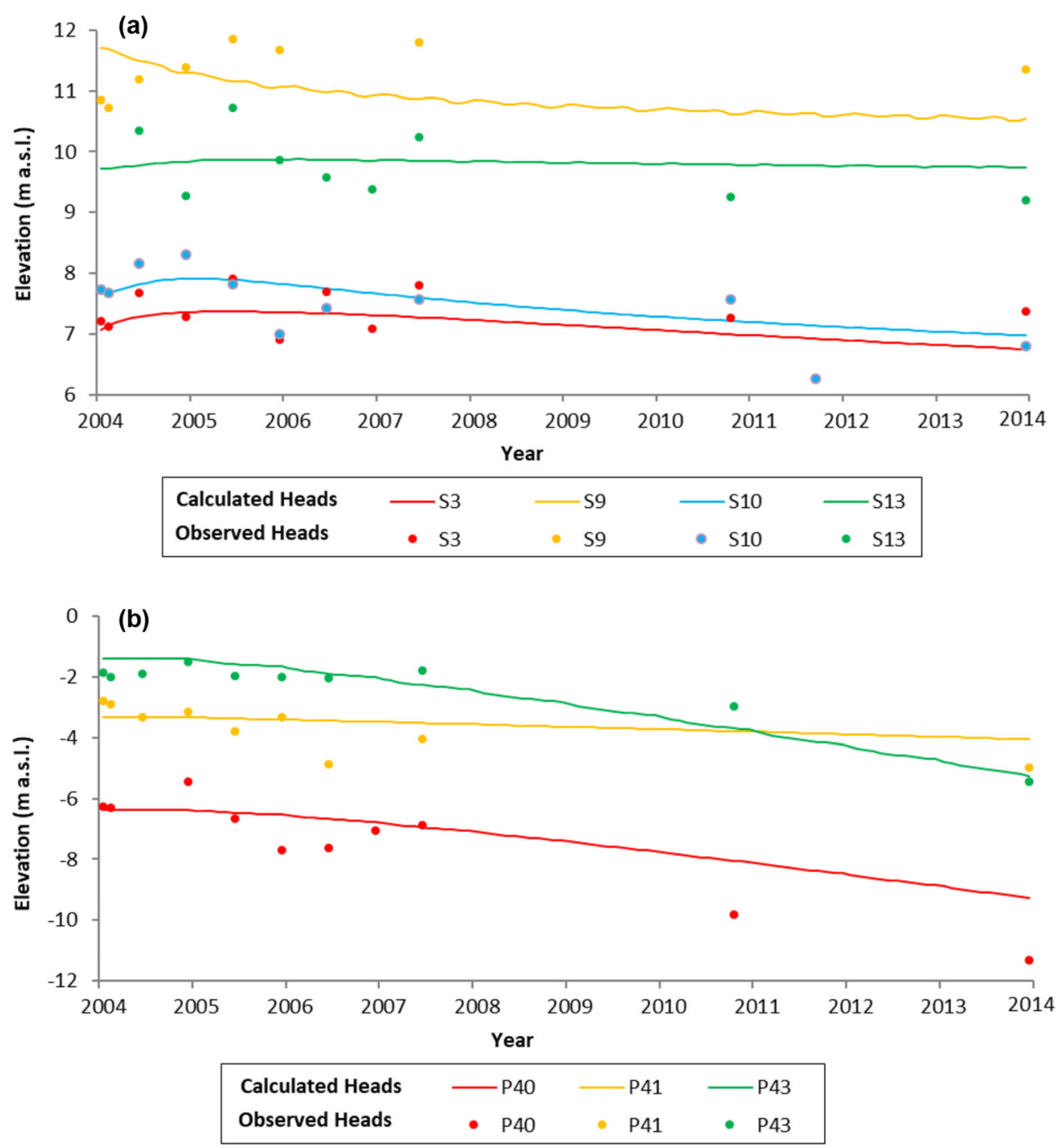

where hydraulic heads show a significant cone of depression in the area of most extraction, around the Piura and Castilla towns, where hydraulic heads drop $16 \mathrm{~m}$ between 2004 and 2014.

The analysis of the water balance and flow transfers for both layers during the period 2004-2014 (Fig. 8) allows for understanding the global situation of the aquifer and changes in local flow patterns. It can be observed that the groundwater flow from/to surfacewater bodies in 2004 has significantly changed in 2014, which is due to hydraulic head increase/decrease in some areas of the upper aquifer which even leads to a reversal of the direction of flow. In areas where the water-table elevation increases, and there are losing surface waters, the hydraulic gradient and flow to the aquifer decreased (zones D and E). In areas where the water-table elevation decreases, and there are losing surface waters, the hydraulic gradient and flow to the aquifer increase (zones $\mathrm{B}$ and $\mathrm{G}$ ). Zones $\mathrm{A}, \mathrm{C}$ and $\mathrm{F}$ are gaining surface waters at the beginning of the simulation, but due to the decreasing water table in these areas, the flow from the aquifer to these zones decrease too, even turning zone $\mathrm{F}$ to a water body with losing condition. Although, in general, the surface-water bodies keep their gaining conditions, the flow transferred to them from the aquifer decreases by $49 \%$ between 2004 and 2014.

On the other hand, the recharge from the Higher Piura Aquifer increases by $22 \%$ because of water-table decrease in the northern part. The red arrows in Fig. 8a,b represents a negative flow of the system, which means that the groundwater flow component transfers from the defined water budget toward aquifer storage. Consequently, the unconfined aquifer keeps storing water in 2014, even though the storage flow decreases by $25 \%$ compared to 2004 . Nonetheless, the increment of pumping abstraction, mainly in the central area, leads to a slight decrease in the water-table elevation in most areas of the model. 


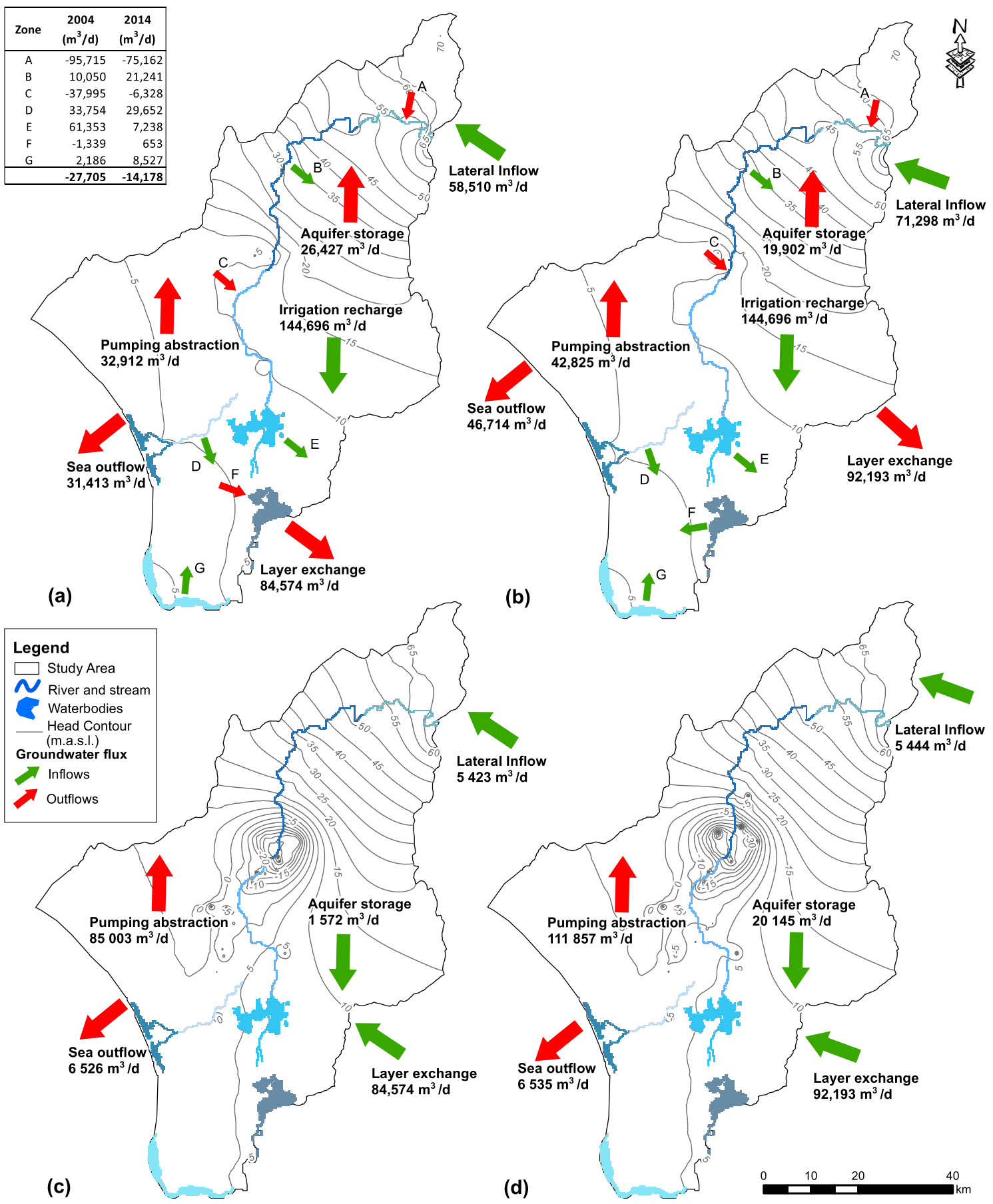

Fig. 8 Water balance components and hydraulic heads for the transient-state simulation in the unconfined aquifer for October 2004 (a), October 2014 (b), and in the confined aquifer for October 2004 (c), October 2014 (d)

The lateral flow and the discharge to the Pacific Ocean in the confined aquifer do not present significant variations between 2004 and 2014; however, stored groundwater released from the confined aquifer to the defined water budget (green arrow in Fig. 8c,d) increases by $1,181 \%$ compared to 2004 , this being a direct response to the increment of pumping abstraction. Although groundwater flow from the unconfined layer toward the confined layer increases by $9 \%$ between
2004 and 2014, this is not enough to cover the pumping abstraction trends. As a result, the confined aquifer releases groundwater from aquifer storage, and consequently, the piezometric surface falls, forming a deeper cone of depression in the central area of the model.

Figure 9a shows the evolution of groundwater fluxes for the entire aquifer. In this figure, the red line represents the flows from/to aquifer storage. When the flow is positive, it 
Fig. 9 Calculated groundwater fluxes for the entire aquifer during the a simulated period, and $\mathbf{b}$ mean monthly water balance components for the transient condition
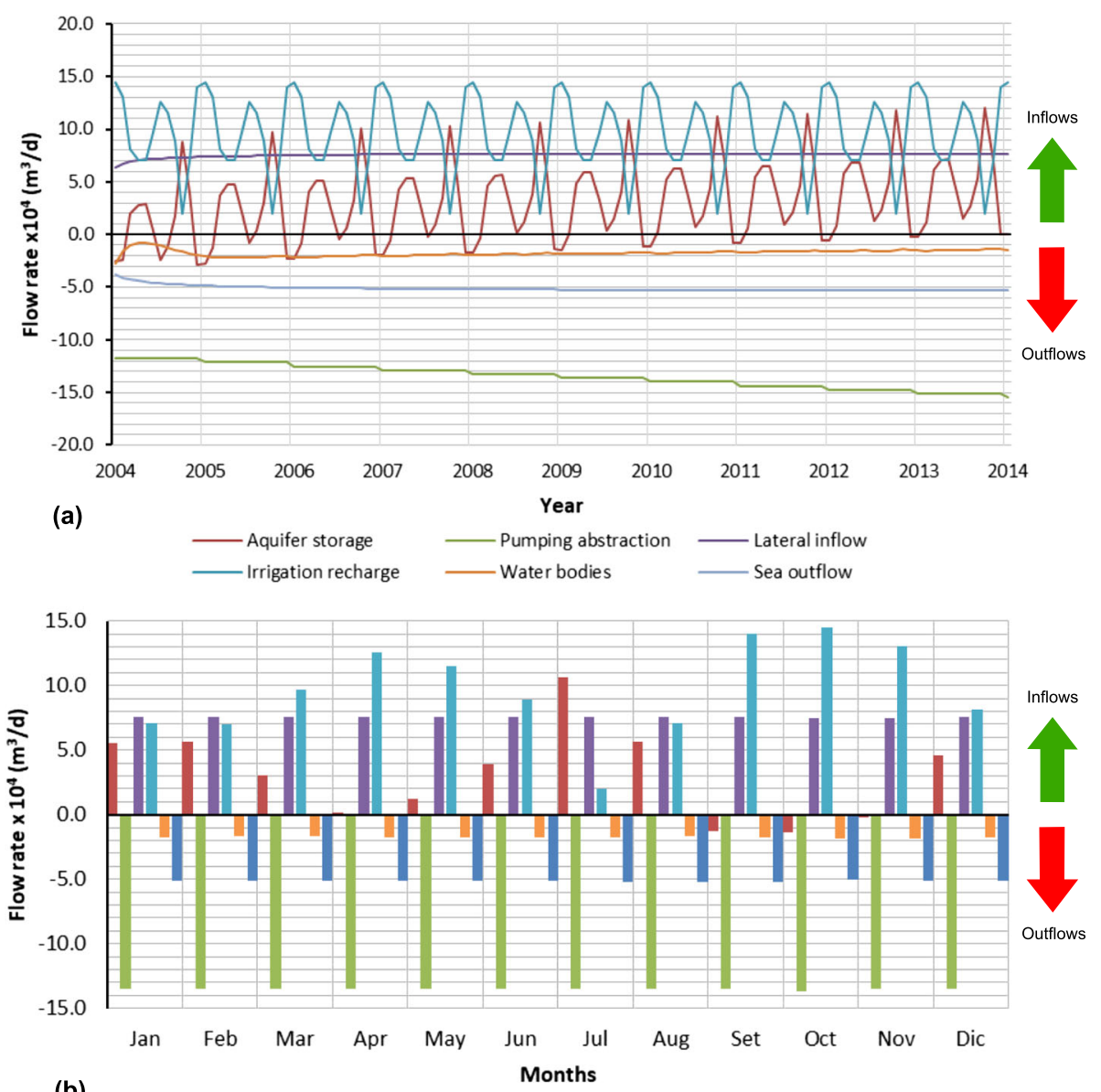

(b)

aquifer storage - Irrigation recharge $\begin{array}{ll}\text { - Pumping abstraction } & \text { Lateral inflow } \\ \text { Water bodies } & \text { Sea outflow }\end{array}$ is describing an inflow from the aquifer storage to the water budget, and when the flow is negative it is indicating the opposite. Thus, the figure shows that the irrigation recharge contributes a significant volume of water to the system and covers the main demands of it (pumping abstraction, flow to rivers, flow to the sea), because the excess water is stored in the unconfined aquifer mainly.

Conversely, if the irrigation recharge decreases, the demands of the system start to be covered by stored groundwater, releasing water from the aquifer storage into the defined water budget. Therefore, if irrigation recharge increases, the aquifer stores water (increase in the negative $y$-axis), and if irrigation recharge decreases a release of groundwater stored in the aquifer occurs (increase in the positive $y$-axis). The seasonal fluctuations of aquifer storage (red line) are due to the unconfined aquifer which stores and releases water with high dependence on the irrigation recharge. However, the increasing trend in the positive $y$-axis shows losses of stored water from the confined aquifer, due to its slower interaction with the surface recharge. The little transient anomaly that can be observed at the beginning of the simulation for surface-water-body transfers-rivers and lakes - has a minor and short impact on the model, which is a consequence of the uncertainty in the initial head conditions. The surface-water bodies, in general, keep their gaining conditions in the modelled period, but there is a flow decrease from the aquifer to them. The flow to the sea shows as a decreasing tendency in the negative $y$-axis, which means that more groundwater is being transferred to the sea. Analysis of the results reveals that current abstraction trends involve pumping stored groundwater from the confined aquifer leading to a fall of hydraulic heads, as can be seen in the cone of depression of Fig. $8 \mathrm{c}, \mathrm{d}$, posing a high risk for the sustainability of this arid region with limited recharge sources.

Figure $9 \mathrm{~b}$ and Table 3 show the mean monthly system flows. These vary mainly depending on infiltration recharge which relies on two agricultural campaigns, January-June and August-December. The highest infiltration recharge occurs in October $\left(144,700 \mathrm{~m}^{3} /\right.$ day), and the lowest occurs in July $\left(20,100 \mathrm{~m}^{3} /\right.$ day $)$. The seasonality of irrigation recharge has a high correlation with the aquifer storage. During months of high irrigation, groundwater coming from the aquifer storage toward the defined water budget decreases, and even in some months, such as September, October, and November, the aquifer stores water (red bars in the negative y-axis). The scarce 
Table 3 Mean annual water budget of the transient model

\begin{tabular}{|c|c|c|c|c|c|c|c|c|c|c|c|c|}
\hline \multirow[t]{2}{*}{ Month } & \multicolumn{2}{|c|}{ Aquifer storage } & \multicolumn{2}{|c|}{ Pumping abstraction } & \multicolumn{2}{|c|}{ Lateral inflow } & \multicolumn{2}{|c|}{ Irrigation recharge } & \multicolumn{2}{|c|}{ Water bodies } & \multicolumn{2}{|c|}{ Sea outflow } \\
\hline & $\begin{array}{l}\times 10^{4} \mathrm{~m}^{3} / \\
\text { day }\end{array}$ & $\begin{array}{l}\times 10^{6} \mathrm{~m}^{3} / \\
\text { year }\end{array}$ & $\begin{array}{l}\times 10^{4} \mathrm{~m}^{3} / \\
\text { day }\end{array}$ & $\begin{array}{l}\times 10^{6} \mathrm{~m}^{3} / \\
\text { year }\end{array}$ & $\begin{array}{l}\times 10^{4} \mathrm{~m}^{3} / \\
\text { day }\end{array}$ & $\begin{array}{l}\times 10^{6} \mathrm{~m}^{3} / \\
\text { year }\end{array}$ & $\begin{array}{l}\times 10^{4} \mathrm{~m}^{3} / \\
\text { day }\end{array}$ & $\begin{array}{l}\times 10^{6} \mathrm{~m}^{3} / \\
\text { year }\end{array}$ & $\begin{array}{l}\times 10^{4} \mathrm{~m}^{3} / \\
\text { day }\end{array}$ & $\begin{array}{l}\times 10^{6} \mathrm{~m}^{3} / \\
\text { year }\end{array}$ & $\begin{array}{l}\times 10^{4} \mathrm{~m}^{3} / \\
\text { day }\end{array}$ & $\begin{array}{l}\times 10^{6} \mathrm{~m}^{3} / \\
\text { year }\end{array}$ \\
\hline Jan & 5.59 & 1.68 & -13.45 & -4.04 & 7.55 & 2.27 & 7.10 & 2.13 & -1.73 & -0.52 & -5.12 & -1.54 \\
\hline Feb & 5.64 & 1.69 & -13.45 & -4.04 & 7.57 & 2.27 & 7.02 & 2.11 & -1.69 & -0.51 & -5.13 & -1.54 \\
\hline Mar & 3.00 & 0.90 & -13.45 & -4.04 & 7.57 & 2.27 & 9.67 & 2.90 & -1.69 & -0.51 & -5.14 & -1.54 \\
\hline Apr & 0.13 & 0.04 & -13.45 & -4.04 & 7.58 & 2.27 & 12.59 & 3.78 & -1.74 & -0.52 & -5.15 & -1.55 \\
\hline May & 1.24 & 0.37 & -13.45 & -4.04 & 7.58 & 2.27 & 11.52 & 3.46 & -1.77 & -0.53 & -5.16 & -1.55 \\
\hline Jun & 3.88 & 1.16 & -13.45 & -4.04 & 7.59 & 2.28 & 8.89 & 2.67 & -1.78 & -0.53 & -5.17 & -1.55 \\
\hline Jul & 10.68 & 3.20 & -13.45 & -4.04 & 7.60 & 2.28 & 2.01 & 0.60 & -1.71 & -0.51 & -5.18 & -1.55 \\
\hline Ago & 5.61 & 1.68 & -13.45 & -4.04 & 7.60 & 2.28 & 7.06 & 2.12 & -1.69 & -0.51 & -5.18 & -1.55 \\
\hline Set & -1.29 & -0.39 & -13.45 & -4.04 & 7.60 & 2.28 & 14.04 & 4.21 & -1.75 & -0.53 & -5.19 & -1.56 \\
\hline Oct & -1.40 & -0.42 & -13.45 & -4.04 & 7.49 & 2.25 & 14.47 & 4.34 & -1.90 & -0.57 & -5.07 & -1.52 \\
\hline Nov & -0.24 & -0.07 & -13.45 & -4.04 & 7.51 & 2.25 & 13.07 & 3.92 & -1.86 & -0.56 & -5.08 & -1.52 \\
\hline Dec & 4.62 & 1.39 & -13.45 & -4.04 & 7.54 & 2.26 & 8.13 & 2.44 & -1.78 & -0.53 & -5.10 & -1.53 \\
\hline Total & & 11.24 & & -48.42 & & 27.23 & & 34.67 & & -6.33 & & -18.50 \\
\hline
\end{tabular}

and insufficient information regarding pumping abstractions led to the authors considering a constant pumping rate every month in every given year. Thus, Fig. 9b shows a constant monthly value of $134,500 \mathrm{~m}^{3} /$ day, which corresponds to the mean monthly abstraction over the whole simulated period. Nonetheless, the total annual abstraction varies according to the available information. Although the temporal variation within every year is not accounted for, the approach taken serves as a reasonably good approximation. The mean monthly values of the lateral inflows from the Higher Piura Aquifer, groundwater outflows to the Pacific Ocean, and flow transfers to surface waters oscillate smoothly, as can be seen in Table 3. The lateral inflow from the Higher Piura Aquifer delivers water to the system throughout the year, while surface-water bodies keep their gaining conditions, receiving water from the aquifer, and finally, groundwater remains flowing to the sea for the entire year.

\section{Conclusions}

\section{General conclusions}

The main study objectives, of improving the characterization and understanding of the Lower Piura Sub-basin Aquifer system, as well as evaluating the impact of anthropic influence on the system, have been accomplished. One of the main conclusions reached is that the aquifer, especially the underlying confined aquifer layer, is being overexploited with pumping rates higher than its recharge. The records of observed hydraulic heads, which have been honoured by the model results, show the decrease in piezometric levels due to aquifer reserve consumption, which represents an overexploitation scenario (Sarah et al. 2014). The most significant amount of water abstraction is from the confined aquifer, which has low interaction with surface recharge sources, as supported by the aquifer model results and previous studies. Thus, if the current exploitation trend is maintained, the piezometric levels will continue to decrease, increasing the abstraction costs, changing the relationships with the surface-water bodies, and potentially changing the direction of groundwater flows raising the risk of future saline intrusion problems. However, as described by Custodio (2002), a persistent groundwater-level drawdown trend is not a sure criterion for deciding whether abstraction is equal to or greater than recharge, nor is the fact that the water quality in some wells is progressively deteriorating. Longterm transient effects may be significant in aquifers. Moreover, recharge may change with development, and the aquifer response depends on the distribution of wells. Consequently, it is necessary to undertake further investigations and gather reliable data on the aquifer over time.

The Lower Piura Sub-basin Aquifer is not the only one with sparse data and deficient studies for its characterization. The study carried out by Bocanegra et al. (2009) includes 15 aquifers across South America, including the Máncora coastal aquifer of Peru. This study reveals some common features between these aquifers such as intensive groundwater exploitation; lack of characterization studies to support resource planning and management; lack of monitoring networks; and the need for raising awareness within society and its involvement in resource planning and management action programmes. This is well corroborated with the results obtained by this study which demonstrates a modelling strategy applicable in many other parts of South America. 
The results of the model in transient-state conditions in the calibration period have allowed assessing the average input and output flows of the system between 2004 and 2014. The aquifer is mainly recharged by irrigation returns that enter the system at an average volume of $34.67 \times 10^{6} \mathrm{~m}^{3} /$ year, followed by the lateral recharge that provides the aquifer with an average volume of $27.23 \times 10^{6} \mathrm{~m}^{3} /$ year. The primary outflow is due to pumping wells with an average value of $48.42 \times$ $10^{6} \mathrm{~m}^{3}$ /year, followed by the average flow discharge to the sea of $18.50 \times 10^{6} \mathrm{~m}^{3} /$ year, and to a lesser extent, the average flow to surface-water bodies of $6.33 \times 10^{6} \mathrm{~m}^{3} /$ year. The water balance has a total inflow of $61.90 \times 10^{6} \mathrm{~m}^{3} /$ year and a total outflow of $73.25 \times 10^{6} \mathrm{~m}^{3} /$ year, this being the difference provided by the aquifer storage with an average annual volume of $11.24 \times 10^{6} \mathrm{~m}^{3} /$ year, with a higher proportion abstracted from the confined aquifer.

Another important conclusion reached is that, in general, surface-water bodies are fed by the aquifer. In the northern part of the model, there is the most significant transfer of flow from the aquifer to the Piura River, and in the southern part, water flows to the aquifer from the lakes and the Virrilla Estuary. However, if analyzed in detail, there is a complicated relationship between these bodies and the aquifer, proving to be highly dependent on the variations of the water table.

It is important to note that the model represents the observed hydraulic heads satisfactorily; therefore, it provides some assurance regarding the hypotheses taken for the elaboration of the conceptual model. As a result, this conceptualization and the model results can be used as a reference in the generation of future models and for the development of aquifer management policies. The calibration of the model was acceptable (Moriasi et al. 2007), both in the steady-state model and in the transient model with NSE 0.97 and 0.96 , respectively. On the other hand, a formal validation process of the model, beyond the application of the expertise criteria, has not been possible due to the limited data available. Regardless, no validation guarantees the ability of a model to predict results, and even a proper calibration does not guarantee that the conceptual model established is the most appropriate as stated by Bredehoeft and Konikow (1993). Even wrong conceptual models can be calibrated and validated, giving the false impression of having an accurate model representing a groundwater system.

Previous modelling attempts made for the Lower Piura Sub-basin Aquifer were those published by the Czech Geological Survey (2010) and by the National Water Authority ANA (2015a), as introduced before. In the former study, the objective of the model was to identify the recharge sources of the confined aquifer qualitatively, and the conclusion reached was that a potential recharge of the confined aquifer comes from zone B of the Piura River, see Fig. 8. This is confirmed by this new model and quantitatively assessed. In the latter study, it is also mentioned that floods produced by extreme events such as ENSO do not represent a source of recharge for the confined aquifer. Although this could not be confirmed in this study, the slow response of the confined aquifer to surface recharge observed in the model suggests that this statement could be correct. In addition, as mentioned by Bolzicco et al. (2013) and Arce (2005), the volume of lateral recharge entering the system from the Higher Piura Aquifer is an essential source of recharge for the Lower Piura Sub-basin Aquifer, and whether or not there is a lateral recharge of the aquifer from the Chira Basin is one of the major uncertainties of the model.

In short, the model presented provides very useful conclusions for water planning and management in this geographical area, but also for other analogue groundwater bodies in South America and around the world. It also demonstrates how to build and calibrate a model with a consistent interpretation of limited data lacking a proper characterization of the hydrogeological formation. Therefore, the model is a framework to foresee future planning scenarios that might diminish the current overexploitation. It seems that the ENSO is not providing significant water inflows that diminish the overexploitation of the confined water body, and surface water bodies are generally fed by the unconfined aquifer, occasionally by the ENSO. This situation calls for the implementation of mechanisms that promote surface water recharge in the upper aquifer, and to analyze different strategies to reduce abstraction trends in the lower aquifer, such as: (1) reallocating abstractions from the confined aquifer to the upper aquifer when water quality requirements make it feasible; (2) using mixed waters, from the upper and lower aquifers, to diminish water abstraction from the lower aquifer; (3) alternating the abstraction from the upper and lower aquifer to maximize recharge in the upper layer and the recovery of the lower layer by lateral recharge.

\section{Model uncertainties and further research}

In general, it can be said that mathematical models are better at deriving an understanding of system dynamics than simulating future scenarios. This is because the errors of parameter estimation and other simplifications can increase, even exponentially, the uncertainty of model results. Besides, the simulated scenarios may pose conditions different from those present in the calibration scenario, and this can even invalidate the validity of the conceptual model for different scenarios. Having said that, this research focused on the objective of improving the understanding of the functioning of the aquifer, and not on predictive simulations. Future efforts should focus on improving the conceptualization of the system and on a more accurate calibration based on new hydrogeological exploration and data collection, which would reduce uncertainties and provide a better basis for predictive simulations. Moreover, it is necessary to mention that this model has been 
built based on average hydrological years; the influence of anomalies or phenomena such as the ENSO, which could allow rapid recovery of the unconfined aquifer's groundwater levels, has not been evaluated.

The uncertainties of the model come mainly from the lack of accurate hydrogeological data over broad areas of the aquifer domain, from the limited knowledge of external stresses such as water abstractions, and the lack of direct measurements of the aquifer behaviour beyond the more exploited zones. The length of the calibration period and the lack of data at a monthly scale also pose a significant limitation to the resulting model. Lastly, there is also the need for a hydrogeological study where the geophysical data are correlated with the stratigraphy of the area, to define with greater precision the geometry of the model domain, including the area and width of the strata.

Acknowledgements The authors express sincere gratitude to the stakeholders and engineers who collaborated with advice and opinions to the successful completion of this research work. We are grateful to all the lecturers and staff for their support during the collaborative work at Universitat Politècnica de València. We are also very thankful to the National Water Authority of Peru for their support in data collection and useful reports.

Funding information We thank the Government of Peru Scholarship for the financial support of this research.

Open Access This article is distributed under the terms of the Creative Commons Attribution 4.0 International License (http:// creativecommons.org/licenses/by/4.0/), which permits unrestricted use, distribution, and reproduction in any medium, provided you give appropriate credit to the original author(s) and the source, provide a link to the Creative Commons license, and indicate if changes were made.

\section{References}

ANA (2009a) Actualización del Inventario de Fuentes de Agua Subterránea del Valle Alto Piura [Update of the Inventory of groundwater sources of the Higher Piura Valley]. National Water Authority, Lima, Peru

ANA (2009b) Actualización de la propuesta de asignación de agua en bloques, volúmenes anuales y mensuales para la consolidación de la formalización de derechos de uso de agua en el Medio y Bajo Piura Valley [Update of the water allocation proposal in blocks, annual and monthly volumes for the consolidation of the formalization of water use rights in the Middle and Lower Piura Valley]. National Water Authority, Lima, Peru

ANA (2011) Caracterización hidrogeológica del acuífero del Medio y Bajo Piura Valley [Hydrogeological characterization of the Middle and Lower Piura Valley aquifer]. National Water Authority, Lima, Peru

ANA (2012a) Caracterización Hidrogeológica del Acuífero del Medio y Bajo Piura Valley [Hydrogeological characterization of the Middle and Lower Piura Valley aquifer]. National Water Authority, Lima, Peru

ANA (2012b) Diagnóstico de la gestión de los recursos hídricos de la cuenca Chira-Piura: Informe principal [Assessment of the management of the water resources of the Chira-Piura Basin: Main Report]. National Water Authority, Lima, Peru. http://repositorio. ana.gob.pe/handle/ANA/1962. Accessed 04 April 2017

ANA (2015a) Evaluación de Recursos hídricos superficiales en la Cuenca del Río Piura Tomo I y II [Evaluation of surface water resources in the Piura River Basin volumes I and II]. National Water Authority, Lima, Peru. http://repositorio.ana.gob.pe/handle/ANA/2031. Accessed 04 April 2017

ANA (2015b) Plan de gestión de los recursos hídricos de la cuenca ChiraPiura [Management plan of water resources of Chira-Piura Basin]. National Water Authority, Lima, Peru. http://repositorio.ana.gob.pe/ handle/ANA/87. Accessed 04 April 2017

Anderson MP, Woessner WW (1992) Applied groundwater modeling: simulation of flow and advective transport. Academic, San Diego, $381 \mathrm{pp}$

Arce J (2005) Potencial Geofísico Exploratorio de los Acuíferos Terciarios Regionales del Perú, Volumen Especial N ${ }^{\circ} 06$ [Exploratory geophysical potential of the Tertiary Regional Aquifers of Peru, special volume no. 06]. Geological Society of Peru, Lima. http://www.sgp.org.pe/category/bibliovirtual/?result= 6891. Accessed 04 April 2017

Bear J, Verruijt A (1987) Modeling groundwater flow and pollution. Reidel, Dordrecht, The Netherlands, $414 \mathrm{pp}$

Bocanegra E, Silva G Jr, Custodio E, Manzano M, Montenegro S (2009) State of knowledge of coastal aquifer management in South America. Hydrogeol J 18:261-267. https://doi.org/10.1007/ s10040-009-0520-5

Bredehoeft J, Konikow L (1993) Ground-water models: validate or invalidate. Ground Water 31(2):178-179. https://doi.org/10.1111/j. 1745-6584.1993.tb01808.x

Bolzicco J, García J, Ortiz R, Ludeña A, Jurado M, Diaz G, Estrada F, Huerta F (2013) Investigaciones hidrogeológicas Acuífero El Zapallal Perú, tomo I: agua subterránea recurso estratégico [Hydrogeological investigations of Aquifer El Zapallal Peru, vol I: groundwater strategic resource]. National University of La Plata, La Plata, Argentina, pp 164-169

Class-Salzgitter (2001) Estudio Ddfinitivo para la reconstrucción y rehabilitación del sistema de defensas contra inundaciones en el Bajo Piura [Definitive study on the reconstruction and rehabilitation of the protection systems against floods in Lower Piura River]. Class-Salzgitter Consortium, Special project, Chira-Piura, Peru

Custodio E (2002) Aquifer overexploitation: what does it mean? Hydrogeol J 10:254-277. https://doi.org/10.1007/s10040-0020188-6

Czech Geological Survey (2010) Evaluación de las condiciones geomorfológicas e hidrogeológicas de las cuencas bajas del Río Piura y Río Chira para mitigar factores ambientales que restringen el desarrollo social y económico de las regiones: reporte final [Evaluation of the geomorphological and hydrogeological conditions of the lower basins of Piura River and Chira River to mitigate environmental factors that restrict the social and economic development of the regions: final report]. Czech Geological Survey, Prague, Czech Republic. http://repositorio.ana.gob.pe/handle/ANA/33. Accessed 04 April 2017

Doherty J (2016) PEST model-independent parameter estimation user manual part I: PEST, SENSAN and Global Optimisers. Watermark, Brisbane, Australia. http://www.pesthomepage.org/ getfiles.php?file=newpestman1.pdf. Accessed 04 April 2017

Galecio J (2004) Diseño de defensas ribereñas del río Piura en el tramo presa Los Ejidos - Puente Cáceres [Design of riverside defenses of the Piura River between Los Ejidos dam and Cáceres Bridge]. Degree final project, University of Piura, Peru. https://pirhua.udep. edu.pe/handle/123456789/1167. Accessed 04 April 2017

GEOCATMIN (2017) Webpage of Peru Geological and Metallurgical Institute. http://geocatmin.ingemmet.gob.pe/geocatmin/index.html. Accessed 04 April 2017 
Geoservidor MINAM (2017) Webpage of Ministry of the Environment of Peru. http://geoservidor.minam.gob.pe/. Accessed 04 April 2017

Gore Piura (2017) Mejoramiento del Servicio de Protección Contra Inundaciones de las ciudades de Piura y Castilla, margen derecha e Izquierda del Río Piura en el Tramo: Presa Los Ejidos al Puente Cáceres [Improvement of the flood protection service of the cities Piura and Castilla, right and left side of the Piura River between sections Los Ejidos Dam to Cáceres Bridge]. Regional Government of Piura, Peru

Harbaugh A (2005) MODFLOW-2005, The U.S. Geological Survey modular ground-water model: the ground-water flow process. US Geol Surv Techniques and Methods 6-A16. https://pubs.er.usgs.gov/ publication/tm6A16. Accessed 04 April 2017

Horel JD, Cornejo-Garrido AJ (1986) Convection along the coast of northern Peru during 1983: spatial and temporal variation of clouds and rainfall. Mon Weath Rev 114:2091-2104

INGEMMET (1994) Geología de los cuadrángulos de Paita, Piura, Talara, Sullana, Lobitos, Quebrada Seca, Zorritos, Tumbes y Zarumilla 11-a, 11-b, 10-a, 10-b, 9-a, 9-b, 8-b, 8-c, 7-c Boletín A 54 [Geology of the quadrangles of Paita, Piura, Talara, Sullana, Lobitos, Quebrada Seca, Zorritos, Tumbes and Zarumilla 11-a, 11b, 10-a, 10-b, 9-a, 9-b, 8-b , 8-c, 7-c Bulletin A 54]. Instituto Geológico, Minero y Metalúrgico del Perú. http://repositorio. ingemmet.gob.pe/handle/ingemmet/175. Accessed 04 April 2017

INRENA (2004) Inventario de Fuentes de Agua Subterránea en el Medio y Bajo Piura Valley [Inventory of groundwater sources in the Middle and Lower Piura Valley]. National Institute of Natural Resources, Lima, Peru. http:/www.ana.gob.pe/sites/default/files/normatividad/ files/fuente_agua_subterranea_medio_bajo_piura_0_0_3.pdf. Accessed 04 April 2017

Freeze RA, Cherry JA (1979) Groundwater. Prentice-Hall, Englewood Cliffs, NJ, 604 pp

Kinzelbach W (1986) Groundwater modeling: an introduction with sample programs in BASIC. Elsevier, New York, 333 pp

Konikow L, Bredehoeft J (1992) Ground-water models cannot be validated. Adv Water Resour 15(1):75-83

Molinero J, Candela L, Jiménez-Martínez J (2009) Estimación de la recarga por retornos de riego a través de la ZNS en áreas de agricultura intensiva bajo clima semi-árido. Análisis de Sensibilidad [Estimation of the recharge for irrigation returns through the ZNS in areas of intensive agriculture under semi-arid climate: sensitivity Analysis]. Polytechnic University of Catalonia, Spain pp 522-529

Moriasi D, Arnold J, Van Liew M, Bingner R, Harmel R, Veith T (2007) Model evaluation guidelines for systematic quantification of accuracy in watershed simulations. Trans ASABE 50(3):885-900. https://doi.org/10.13031/2013.23153

Murphy R (1926) Oceanic and climatic phenomenon along the west coast of South America during 1925. Geogr Rev 16:26-54

ONERN (1980) Inventario y evaluación de las fuentes de agua subterránea en el valle de Piura, departamento de Piura [Inventory and evaluation of groundwater sources in the Piura Valley, department of Piura]. National Office for the Evaluation of Natural Resources. http://repositorio.ana.gob.pe/handle/ANA/1055. Accessed 04 April 2017

PNUD (2000) Estudio para el Tratamiento Integral del Río Piura [Study for the Integral Treatment of the Piura River]. United Nations Development Programme. http://siar.regionpiura.gob.pe/ admDocumento.php?accion=bajar\&docadjunto=204. Accessed 04 April 2017

Proyecto Especial Chira-Piura (2017) Webpage of Chira-Piura Special Project, Peruvian Local Government Institution. http://www. chirapiura.gob.pe. Accessed 04 April 2017

Rabus B, Eineder M, Roth A, Bamler R (2002) The shuttle radar topography mission: a new class of digital elevation models acquired by spaceborn radar. J Photogramm Remote Sens 57(2003):241-262

Sarah S, Ahmed S, Boisson A, Violette S, Marsily G (2014) Projected groundwater balance as a state indicator for addressing sustainability and management challenges of overexploited crystalline aquifers. J Hydrol 519(2014):1405-1419. https://doi.org/10.1016/j.jhydrol. 2014.09.016

Schuckmann K, Le Traon P, Alvarez-Fanjul E, Axell L, Balmaseda M, Breivik LA, Brewin RJ, Bricaud C, Drevillon M, Drillet Y, Dubois C, Embury O, Etienne H, García M, Garric G, Gasparin F, Gutknecht E, Guinehut S, Hernandez F, Juza M, Karlson B, Korres G, Legeais JF, Levier B, Lien V, Morrow R, Notarstefano G, Parent L, Pascual A, Pérez-Gómez B, Perruche C, Pinardi N, Pisano A, Poulain PM, Pujol IM, Raj RP, Raudsepp U, Roquet H, Samuelsen A, Sathyendranath S, She J, Simoncelli S, Solidoro C, Tinker J, Tintoré J, Viktorsson L, Ablain M, Almroth-Rosell E, Bonaduce A, Clementi E, Cossarini G, Dagneaux Q, Desportes C, Dye S, Fratianni C, Good S, Greiner E, Gourrion J, Hamon M, Holt J, Hyder P, Kennedy J, Manzano-Muñoz F, Melet A, Meyssignac B, Mulet S, Buongiorno B, O'Dea E, Olason E, Paulmier A, PérezGonzález I, Reid R, Racault MF, Raitsos DE, Ramos A, Sykes P, Szekely T, Verbrugge N (2016) The Copernicus Marine Environment Monitoring Service ocean state report. J Oper Oceanogr 9(supp12):s235-s320. https://doi.org/10.1080/ 1755876X.2016.1273446

SEA (2012) Guía para el uso de modelos de aguas subterráneas en el SEIA [Guide for the use of groundwater models in the SEIA]. Ministry of the Environment of Chile, Environmental Assessment Service. http://www.sea.gob.cl/sites/default/.../guias/Guia_uso_ modelo_aguas_subterraneas_seia.pdf. Accessed 04 April 2017

Simcore Software (2012) An integrated modeling environment for the simulation of groundwater flow, transport and reactive processes. Simcore. https://www.simcore.com/files/pm/v8/pm8.pdf. Accessed 04 April 2017

Tapley D, Waylen P (1990) Spatial variability of annual precipitation and ENSO events in western Peru. Hydrol Sci J 35(4):429-446. https:// doi.org/10.1080/02626669009492444 